\title{
УНИФИКАЦИЯ НОРМ О МЕЖДУНАРОДНОЙ СУДЕБНОЙ ЮРИСДИКЦИИ В МЕЖДУНАРОДНОМ ПРОЦЕССУАЛЬНОМ ПРАВЕ
}

\begin{abstract}
Аннотация. Настоящая статья посвящена рассмотрению актуальных вопросов, связанных с унификацией норм о международной судебной юрисдикиии в международном прочессуальном праве, которое понимается авторами как отрасль международного частного права. Авторы рассматривают три группы вопросов: установление международной судебной юрисдикиии в национальном российском законодательстве и международных договорах, в которых участвует Россия; установление международной судебной юрисдикции в национальном праве Англии, США и Франции; особые судебные приказы и итрафы в английском, американском и франиузском праве. Авторы анализируют виды международной судебной юрисдикиии, включающие общую, исключительную и договорную юрисдикиию, а также подробно исследуют такой не известный международному гражданско-процессуальному праву России институт, как доктрина fогит поп conveniens. Существенное внимание уделено авторами особым судебным приказам английских, американских и франиузских судов, включающих судебный приказ о запрете иностранного судопроизводства (anti-suit injunction); судебный приказ о наложении ареста на активы ответчика (Mareva injunction), а также особому судебному штрафу (astreinte).

Ключевые слова: судебная юрисдикиия, государственный суд, прогрогационное соглашение, гражданское судопроизводство, судебный приказ, судебный запрет, проиессуальный институт, судебный штраф, судебная доктрина, международное проиессуальное право

Review: This article is devoted to the topical issues regarding unification of the norms on international judicial jurisdiction in the international procedural law, which is regarded by the authors as a branch of international private law. The authors view three groups of issues: establishing international judicial jurisdiction in the Russian domestic legislation and international treaties, to which Russia is a party, establishing international judicial jurisdiction in the domestic law of England, USA and France, special judicial injunctions and fines in English, American and French law. The authors analyze types of international judicial jurisdiction, including, general, exclusive and treaty-based jurisdiction, and also study an institution of "forum non conveniens", which is not known to the international civil procedural law of Russia. Much attention is paid by the authors to the special judicial orders of English, American and French courts, including the anti-suit injunctions, Mareva injunction, and astreinte.

Keywords: judicial jurisdiction, state court, prorogation treaty, civil judicial procedure, judicial injunction, judicial prohibition, procedural institution, judicial fine, judicial doctrine, international procedural law.
\end{abstract}

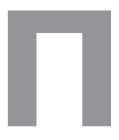

роцесс глобализации мировой экономики и обусловленное этим широкое вовлечение российских предприятий и предпринимателей во внешнеэкономическую деятельность предопределило усиление роли и значения судебных органов при разрешении международных коммерческих споров. Юрисдикция судов по внешнеэкономическим спорам является предметом регулирования со стороны международного частного права, а именно одной из его важнейших отраслей - международного процессуального права. Последнее представляет собой отрасль МЧП, состоящую из норм национального законодательства и международных договоров, которые регулируют международные процессуальные отношения (процессуальные отношения, осложненные иностранным элементом). Объектом международного процессуального права высту- 
пает процедура разрешения международных частноправовых споров в государственных судах и коммерческих арбитражах, поэтому в нем выделяются две отрасли, одновременно выступающие как подотрасли МЧП в целом - международное гражданско-процессуальное право ${ }^{1}$ и международное арбитражно-процессуальное право.

При всем многообразии подходов к определению правовой природы международного гражданского процесса в науке МЧП выделяются его несколько отличительных признаков, которые в той или иной степени поддерживаются всеми учеными:

1. международный гражданский процесс носит публично-правовой характер, поскольку он представляет собой властную деятельность государственных органов - судов - по отправлению правосудия по трансграничным гражданским делам. Все участники процесса, в том числе иностранные лица, всегда находятся в юридическом подчинении по отношению к судам;

2. несмотря на то, что суд каждого государства отправляет правосудие по своим процессуальным правовым нормам, международный гражданский процесс по своему содержанию носит экстерриториальный характер. Это выражается в неизбежной взаимосвязи и взаимозависимости как судебных систем

\footnotetext{
${ }^{1}$ См.: Яблочков T.M. Курс международного гражданского процессуального права. Ярославль, 1909; Юрова Н.М. Международное гражданское процессуальное право: Теоретические основы имплементации норм в правовой системе РФ. М., 2008; Елисеев Н.Г., Вершинина Е.В. Международное гражданское процессуальное право: Учебное пособие. М., 2011; Grubbs S. (ed.) International Civil Procedure (World Law Group Series). Kluwer Law International, 2003; Campbell C. (ed.) International Civil Procedure: 2 vols. Lulu.com, 2006-2007; Hartley T. International Commercial Litigation: Texts, Cases and Materials on Private International Law. Cambridge University Press, 2009; Warne J. International Commercial Dispute Resolution. Bloomsbury Professional, 2009; Fentiman $R$. International Commercial Litigation. Oxford University Press, 2010; Hill J., Chong A. International Commercial Disputes: Commercial Conflict of Laws in English Courts. Hart Publishing, 2010; Kramer X.E., van Rhee C.H. (eds.) Civil Litigation in a Globalising World. T.M.C. Asser Press, 2012; Lascelles G. The International Comparative Legal Guide to Litigation and Dispute Resolution 2012 (International Comparative Legal Guide Series). Global Legal Group Ltd., 2012; Milmo M. (ed.) International Litigation Procedure 2012. Sweet and Maxwell, 2013.
}

разных государств, так и их правовых систем при рассмотрении каждого трансграничного гражданского дела (применение иностранного права к спорному материальному отношению; выдача судебного поручения о допросе свидетеля, находящегося за рубежом; исполнение на своей территории решения, вынесенного иностранным судом и пр.);

3. нормы международного гражданского процесса содержатся как в международных договорах, так и в национальном законодательстве каждого государства;

4. конечной целью международного гражданского процесса является разрешение трансграничных споров, а также иных вопросов частноправового характера, относящихся к компетенции государственных судов.

На основании указанных признаков А.А. Мамаев формулирует следующее определение международного гражданского процесса. Международный гражданский процесс - это регулируемая национальным законодательством и международными договорами публично-правовая деятельность государственных судов по отправлению правосудия по трансграничным гражданским делам, носящая экстерриториальный характер и направленная на разрешение трансграничных споров, а также иных вопросов частноправового характера ${ }^{2}$. В этом контексте можно утверждать, что международное гражданско-процессуальное право представляет собой подотрасль МЧП, состоящую из норм национального законодательства и международных договоров, которые регулируют международные процессуальные отношения по рассмотрению государственными судами частноправовых споров, осложненных иностранным элементом.

\footnotetext{
${ }^{2}$ См.: Мамаев A.A. Международная судебная юрисдикция по трансграничным гражданским делам. М., 2008. С. 13-14. См. также: Васильчикова Н.А. Международный гражданский процесс как составная часть внутригосударственного гражданского процессуального права // Арбитражный и гражданский процесс. 2003. № 3; Осавелюк Е.A. К вопросу о месте международного процессуального права в системе российского права // Арбитражный и гражданский процесс. 2003. № 11; Осавелюк E.A. Понятие и предмет международного гражданского процессуального права // Международное публичное и частное право. 2004. № 6.
} 


\section{§ 1. Международная судебная юрисдикция в российском праве}

В настоящее время в науке МЧП не существует общепринятой терминологии для определения процессуальной юрисдикции по гражданским делам с участием иностранных лиц. Применение многочисленных терминов («международная подведомственность», «юрисдикция», «общая компетенция», «международная подсудность» и т.д.) порождает в теории серьезные коллизии: нередко один и тот же термин у разных исследователей используется для определения разных правовых явлений (например, «юрисдикция», от лат. jurisdictio - суд, судопроизводство). И наоборот, одно и то же правовое явление ученые зачастую обозначают совершенно различными терминами (например, разграничение компетенции по рассмотрению гражданских дел между судами разных государств определяется разными исследователями как «международная подсудность», «международная подведомственность» и т.д.). Анализ трудов исследователей в области международного частного права и гражданского процесса позволил А.А. Мамаеву прийти к следующим выводам:

1) Наиболее часто употребляющийся в российской правовой доктрине термин «международная подсудность» представляется достаточно неудобным и нецелесообразным. В отечественной науке МЧП рассмотрение гражданских дел с иностранным элементом в судебном порядке традиционно изучалось отдельно от рассмотрения таких дел третейскими судами. Как следствие, институт судебной подведомственности указанных дел также изучался отдельно от института арбитражной подведомственности. В этой ситуации использование термина «международная подсудность» являлось приемлемым и оправданным: этим термином обозначалось разграничение предметов ведения исключительно между судебными органами разных государств. Подведомственность же гражданских дел с иностранным элементом третейским судам или административным органам того или иного государства, как правило, обозначалась в трудах российских ученых нейтральным термином «компетенция».
Такое раздельное рассмотрение данных процессуальных институтов вряд ли является удачным. Юрисдикция судов разных государств по гражданским делам (трактующаяся в науке как «международная подсудность») и юрисдикция административных органов и арбитражей (именующаяся «компетенцией») по своей юридической природе являются составными частями комплексного понятия «международная процессуальная юрисдикция по гражданским делам». Их невозможно рассматривать строго по отдельности, без учета их тесного единства и взаимосвязи. На основании этого представляется, что наиболее удачным термином для определения разграничения компетенции по рассмотрению гражданских дел с участием иностранных лиц между судебными и иными органами разных государств будет являться термин «международная процессуальная юрисдикция».

В свою очередь, единый комплексный институт международной процессуальной юрисдикции будет подразделяться на «международную судебную юрисдикцию» (определение компетенции судебных органов того или иного государства для разрешения конкретного гражданского дела, иными словами, тот институт, который в настоящее время называется «международной подсудностью»), «международную административную юрисдикцию» (определение компетенции административно-распорядительных органов разных государства по рассмотрению дел с иностранным элементом), «международную арбитражную юрисдикцию» (определение компетенции третейских судов, расположенных в разных государствах, по рассмотрению указанной категории гражданских дел) и т.д. Исходным при определении компетенции какого-либо правоприменительного органа того или иного государства для рассмотрения конкретного гражданского дела с иностранным элементом должно служить понятие «международной процессуальной юрисдикции».

2) Применение термина «международная процессуальная юрисдикция» является оправданным и с практической точки зрения. В каждом конкретном случае, когда возникает спор между субъектами материального правоотношения либо появляется иная необходимость обращения к правомочному юрисдикционному органу, всегда 
в первую очередь возникает вопрос: являются ли российские правоприменительные органы компетентными рассматривать конкретное гражданское дело с иностранным элементом, или более широко, в компетенцию системы правоприменительных органов какого государства входит рассмотрение данного гражданского дела по существу, а не вопрос: к компетенции судов какого государства отнесено данное дело.

Существуют определенные категории дел, разрешение которых в законодательстве разных государств не является прерогативой судов, а входит в компетенцию административных органов (например, некоторые семейные дела или дела, связанные с личным состоянием. Кроме того, в ряде случаев обеспечение и защита субъективных гражданских прав осуществляется органами нотариата). Существуют также категории гражданских дел, которые могут быть рассмотрены в некоторых государствах лишь общественными организациями (например, рассмотрение трудовых споров нередко относится к ведению профсоюзов или специальных трудовых арбитражей, а большинство внешнеэкономических споров разрешается в настоящее время третейскими судами). Таким образом, в каждом случае в первую очередь решается вопрос именно о «международной процессуальной юрисдикции», а не о «международной подсудности».

3) В пользу термина «международная процессуальная юрисдикция» можно привести и такой аргумент. Понятия «подведомственность» и «подсудность» используются только в русском языке, и в российской процессуальной науке они носят только внутригосударственное смысловое значение. В науке МЧП термин «международная подсудность» носит условный характер. То же самое можно сказать и о термине «международная подведомственность». Понятие же «юрисдикция», этимологически вышедшее из латинского языка, является созвучным и одинаковым по своему значению во многих языках мира. Таким образом, данный термин является более удобным и практически оправданным с точки зрения именно международного гражданского процесса, поскольку, в отличие от терминов «подведомственность» и «подсудность», является более «интернациональным».
Сам по себе термин «юрисдикция» имеет очень много значений, поэтому для определения компетентной системы правоприменительных органов того или иного государства для рассмотрения гражданского дела с иностранным элементом А.А. Мамаев предлагает использовать термин «международная процессуальная юрисдикция». Понятия же «подведомственность» и «подсудность», по его мнению, должны использоваться в гражданском процессуальном праве России только во внутригосударственном значении ${ }^{3}$. Институт международной процессуальной юрисдикции классифицируется на несколько видов. Анализ этого института позволяет прийти к выводу, что такая юрисдикция в зависимости от степени определенности делится на определенную и неопределенную.

Определенная международная процессуальная юрисдикция - это процессуальный институт, устанавливающий, в компетенцию каких правоприменительных органов (судебных, административных или общественных) того или иного государства входит рассмотрение данного гражданского дела с иностранным элементом. Данный вид юрисдикции определяет не только конкретное государство, но и управомоченную систему органов этого государства (суды, административно-распорядительные органы и т.д.). Примером такого вида международной процессуальной юрисдикции может служить правило, установленное в ч. 1 ст. 20 Минской конвенции СНГ 1993 г. о правовой помощи и правовых отношениях по гражданским, семейным и уголовным делам (далее - Минская конвенция) в редакции Московского протокола 1997 г. (далее - Московский протокол) $)^{4}$, согласно которой иски к лицам, имеющим место жительства на территории одной из Договаривающихся сторон, предъявляются независимо от их гражданства в суды этой Договаривающейся стороны, а иски к юридическим лицам предъявляются в суды Договаривающейся стороны, на территории ко-

\footnotetext{
${ }^{3}$ См.: Мамаев А.А. Указ. соч. С. 36-44.

${ }^{4}$ БМД. 1995. № 2; 2008. № 4. Минская конвенция вступила в силу 19 мая 1994 г. После ратификации для России она вступила в силу 10 декабря 1994 г. Московский протокол вступил в силу 17 сентября 1999 г. После ратификации для России он вступил в силу 09 января 2001 г.
} 
торой находится орган управления юридического лица, его представительство либо филиал. В данном случае правовая норма указывает не только на определенное государство, но и на конкретную систему органов этого государства (судебную систему), компетентную рассматривать гражданские дела с иностранным элементом.

Неопределенная международная процессуальная юрисдикция - это процессуальный институт, с помощью которого устанавливается только государство, в компетенцию органов которого входит рассмотрение конкретного гражданского дела с иностранным элементом. При этом не указывается, какие органы данного государства (судебные или иные) управомочены рассматривать данное дело. В качестве примера неопределенной международной процессуальной юрисдикции можно привести ч. 1 ст. 29 Минской конвенции, согласно которой по делам о расторжении брака компетентны учреждения Договаривающейся стороны, гражданами которой являются супруги в момент подачи заявления. Если на момент подачи заявления оба супруга проживают на территории другой Договаривающейся стороны, то компетентны также учреждения этой Договаривающейся стороны. В приведенном примере содержится определение только конкретного государства, учреждения которого правомочны рассматривать дела о расторжении брака с иностранным элементом. Что же это за «учреждение» - суды, административные органы, церковные организации или что-то еще, - данное правило не устанавливает. Это будет определено лишь с помощью правовых норм о внутригосударственной подведомственности, содержащихся в законодательстве указанного государства ${ }^{5}$.

Говоря о международной процессуальной юрисдикции по гражданским делам, нельзя не отметить следующее. Правовые принципы, положенные в основу определения компетентного органа того или иного государства, содержащиеся в международных договорах, национальном законодательстве и судебной практике разных стран, весьма разнообразны, но они могут быть сведены к некоторым типовым случаям. Из них наиболее часто используемыми являются следующие принципы:

\footnotetext{
${ }^{5}$ См.: Мамаев А.A. Указ. соч. С. 46-47.
}

a) установление юрисдикции по признаку гражданства сторон или стороны в деле (forum patriae);

б) установление юрисдикции по признаку места жительства ответчика (actor sequitur forum rei);

в) установление юрисдикции по признаку места жительства (для юридических лиц - места нахождения) стороны по делу (forum domicilii);

г) установление юрисдикции по признаку личного присутствия ответчика или наличия его имущества на территории данного государства (actor sequitur forum domicilii);

д) установление юрисдикции по признаку места нахождения спорной вещи (forum rei sitae);

е) установление юрисдикции по признаку места совершения акта (forum loci actus);

ж) установление юрисдикции по признаку места исполнения обязательства (forum loci solutionis);

3) установление юрисдикции по признаку места совершения деликта (forum loci delicti commissi);

и) установление юрисдикции по соглашению сторон (forum voluntatis) ${ }^{6}$.

Перечень таких принципов не является исчерпывающим. В разных государствах применительно к разным категориям гражданских дел законодательство может устанавливать и другие принципы, в соответствии с которым определяется компетентный правоприменительный орган в конкретной стране. Например, при установлении международной процессуальной юрисдикции по семейным делам может использоваться признак места заключения брака (forum loci celebrationis); при определении юрисдикции по трудовым делам может использоваться признак места осуществления трудовых обязанностей (forum loci laboris); в ряде случаев устанавливается, что дело может рассматриваться по месту нахождения истца (например, в гражданских делах, связанных с защитой прав потребителей) и т.д. Указанные принципы необходимо отличать от привязок коллизионных норм МЧП, содержащихся в международных договорах и национальном законодательстве всех государств. Несмотря на внешнее сходство тех и других, следует подчеркнуть, что нормы, определяющие международную процес-

\footnotetext{
${ }^{6}$ Там же. С. 49-50.
} 
суальную юрисдикцию, и коллизионные нормы - это разные правовые категории ${ }^{7}$

По степени определенности соглашения о международной процессуальной юрисдикции (пророгационные соглашения) делятся на относительно определенные и абсолютно определенные. В относительно определенных пророгационных соглашениях указывается не конкретный правоприменительный орган, расположенный в том или ином государстве, а система органов определенного государства. Например, стороны могут в соглашении указать, что спор, возникший или могущий возникнуть в будущем из их правоотношений, подлежит рассмотрению в судах Российской Федерации. В абсолютно определенных пророгационных соглашениях указывается не система органов, а конкретный правоприменительный орган, находящийся в определенном государстве. Примером может служить соглашение сторон о том, что спор, связанный с их правоотношениями, подлежит рассмотрению в Российской Федерации, в Арбитражном суде г. Москвы. Абсолютно определенные судебные пророгационные соглашения устанавливают, что дело подлежит рассмотрению в конкретном суде определенного государства, то есть содержат правила не только международной процессуальной юрисдикции и внутригосударственной подведомственности, но и подсудности. Такие соглашения не могут изменять родовую и исключительную территориальную подсудность гражданских дел, установленную процессуальным законодательством в стране суда ${ }^{8}$.

Юрисдикция российских судов по делам с участием иностранных юридических и физических лиц определена в российском процессуальном законодательстве, а именно, в Арбитражном процессуальном кодексе РФ от 24 июля 2002 г. в ред. от 07 июня 2013 г. ${ }^{9}$ (далее - АПК РФ) и в Гражданском процессуальном кодексе РФ от 14 ноября 2002 г. в ред. от 07 мая 2013 г. ${ }^{10}$ (далее - ГПК РФ). По своему правовому статусу россий-

\footnotetext{
${ }^{7}$ Там же. С. 53.

${ }^{8}$ Там же. С. 52.

${ }^{9}$ СЗ РФ. 2002. № 30. Ст. 3012; 2013. № 23. Ст. 2884. Новая редакция АПК РФ вступила в силу 07 июня 2013 г.

${ }^{10}$ СЗ РФ. 2002. № 46. Ст. 4532; 2013. № 19. Ст. 2326. Новая редакция ГПК РФ вступила в силу 19 мая 2013 г.
}

ские арбитражные суды являются составными частями и звеньями судебной системы России и входят в число федеральных судов наряду с федеральными судами общей юрисдикции (п. 3 ст. 4 Федерального конституционного закона «О судебной системе РФ» от 31 декабря 1996 г. в ред. от 25 декабря 2012 г. ${ }^{11}$; ст. 1 Федерального конституционного закона «Об арбитражных судах в РФ» от 28 апреля 1995 г. в ред. от 06 декабря 2011 г. $\left.^{12}\right)$.

Глава 4 «Компетенция арбитражных судов» АПК РФ и Глава 3 «Подведомственность и подсудность» ГПК РФ наделяют и арбитражные суды, и суды общей юрисдикции правом рассматривать и разрешать в порядке искового производства дела, возникающие из гражданских правоотношений с участием иностранных граждан, лиц без гражданства, иностранных организаций, организаций с иностранными инвестициями, международных организаций (п. 5 ст. 27 АПК РФ и п. 2 ст. 22 ГПК РФ), в том числе дела о признании и приведении в исполнение решений иностранных судов и иностранных арбитражных решений (ст. 32 АПК РФ и п. 1(6) ст. 22 ГПК РФ). Наряду с этим оба кодекса содержат специальные разделы, посвященные отдельным аспектам международного гражданского процесса, среди которых главным выступает вопрос об установлении юрисдикции по спорам, осложненным иностранным элементом, то есть международной юрисдикции российских судов (Раздел V «Производство по делам с участием иностранных лиц» АПК РФ и аналогичный раздел ГПК РФ) ${ }^{13}$.

Сразу же возникает вопрос о том, где проходит разграничительная линия, позволяющая отделить компетенцию арбитражных судов от компетенции судов общей юрисдикции по спорам с участием иностранных лиц. Достаточно четкий ответ можно найти при анализе соответ-

\footnotetext{
${ }^{11}$ СЗ РФ. 1997. № 1. Ст. 1; 2012. № 53 (ч. 1). Ст. 7572. Новая редакция настоящего закон вступила в силу 01 января 2013 г. ${ }^{12}$ С3 РФ. 1995. № 18. Ст. 1589; 2011. № 50. Ст. 7334. Новая редакция настоящего закон вступила в силу 07 декабря 2011 г. ${ }^{13}$ См. об этом более подробно: Галенская Л.Н. Международный гражданский процесс: понятие и тенденции развития // Бахин C.B. (ред.) Актуальные проблемы международного гражданского процесса: материалы международной конференции. СПб., 2003. С. 1-12; Марышева Н.И. Вопросы кодификации норм международного гражданского процесса в России // Журнал российского права. 2004. № 6.
} 
ствующих процессуальных норм. Арбитражным судам подведомственны дела по экономическим спорам и другие дела, связанные с осуществлением предпринимательской и иной экономической деятельности юридическими лицами и индивидуальными предпринимателями (п. 1-2 ст. 27, ст. 28 АПК РФ). Им же подведомственны дела о признании и приведении в исполнение решений иностранных судов и иностранных арбитражных решений по спорам, возникающим при осуществлении предпринимательской и иной экономической деятельности (ст. 32 АПК РФ).

Суды общей юрисдикции рассматривают и разрешают дела, возникающие из частноправовых отношений (гражданских, семейных, трудовых, жилищных, земельных, экологических и иных), за исключением экономических споров и других дел, отнесенных законодательством к ведению арбитражных судов (п. 3 ст. 22 ГПК РФ). Таким образом, совершенно очевидно, что основным критерием разграничения компетенции арбитражных судов и судов общей юрисдикции по спорам с участием иностранных лиц выступает предмет спора, определяющий его экономический или неэкономический характер, причем экономический характер связан, безусловно, с осуществлением спорящими субъектами предпринимательской или иной хозяйственной деятельности. С учетом вышеизложенного можно утверждать, что главным институтом по разрешению интересующей нас категории гражданских и торговых дел, включающих иностранный элемент, будут арбитражные суды, в силу чего при дальнейшем изложении материала приоритет будет отдан анализу норм арбитражного процессуального законодательства.

Непосредственно вопросам установления юрисдикции российских судов по международным коммерческим спорам посвящен Раздел V АПК РФ «Производство по делам с участием иностранных лиц». В соответствии с п. 1-4 ст. 254 АПК РФ иностранные лица пользуются процессуальными правами и несут процессуальные обязанности наравне с российскими организациями и гражданами. Процессуальные льготы предоставляются иностранным лицам, если они предусмотрены международным договором РФ. Иностранные лица имеют право обращаться в арбитражные суды в РФ по правилам подведом- ственности и подсудности для защиты своих нарушенных или оспариваемых прав и законных интересов в сфере предпринимательской и иной экономической деятельности. Иностранные лица, участвующие в деле, должны представить в арбитражный суд доказательства, подтверждающие их юридический статус и право на осуществление предпринимательской и иной экономической деятельности. В случае непредставления таких доказательств арбитражный суд вправе истребовать их по своей инициативе. Правительством РФ могут быть установлены ответные ограничения (реторсии) в отношении иностранных лиц тех иностранных государств, в которых введены ограничения в отношении российских организаций и граждан ${ }^{14}$.

Основные принципы установления юрисдикции российских арбитражных судов по международным коммерческим спорам изложены в ст. 247 АПК РФ, которая гласит, что арбитражные суды России рассматривают дела по экономическим спорам и другие дела, связанные с осуществлением предпринимательской и иной экономической деятельности, с участием иностранных организаций, международных организаций, иностранных граждан, лиц без гражданства, осуществляющих предпринимательскую и иную экономическую деятельность (иностранных лиц), в случае, если: 1. ответчик находится или проживает на территории РФ либо на территории РФ находится имущество ответчика;

2. орган управления, филиал или представительство иностранного лица находится на территории РФ;

3. спор возник из договора, по которому исполнение должно иметь место или имело место на территории РФ;

4. требование возникло из причинения вреда имуществу действием или иным обстоятельством, имевшими место на территории РФ или при наступлении вреда на территории РФ; 5. спор возник из неосновательного обогащения, имевшего место на территории РФ;

\footnotetext{
${ }^{14}$ См. об этом более подробно: Колесов П.П. Процессуальные гарантии правового статуса иностранных лиц // Бахин С.В. (ред.) Актуальные проблемы международного гражданского процесса: Материалы международной конференции. СПб., 2003. C. 58-66.
} 
6. истец по делу о защите деловой репутации находится в РФ;

7. спор возник из отношений, связанных с обращением ценных бумаг, выпуск которых имел место на территории РФ;

8. заявитель по делу об установлении факта, имеющего юридическое значение, указывает на наличие этого факта на территории РФ;

9. спор возник из отношений, связанных с государственной регистрацией имен и других объектов и оказанием услуг в международной ассоциации сетей Интернет на территории РФ;

10. в других случаях при наличии тесной связи спорного правоотношения с территорией РФ (п. 1 ст. 247 АПК РФ).

Дело, принятое арбитражным судом к своему рассмотрению с соблюдением правил, должно быть рассмотрено им по существу, хотя бы в ходе производства по делу в связи с изменением места нахождения или места жительства лиц, участвующих в деле, или иными обстоятельствами оно станет относиться к компетенции иностранного суда (п. 4 ст. 247 АПК РФ). Следует отметить, что практически аналогичные нормы закреплены и в ст. 402 ГПК РФ, регулирующей компетенцию судов общей юрисдикции по гражданско-правовым спорам с участием иностранных лиц ${ }^{15}$. Согласно ст. 248 АПК РФ к исключительной компетенции арбитражных судов России по делам с участием иностранных лиц относятся дела:

1. по спорам в отношении находящегося в государственной собственности РФ имущества, в том числе по спорам, связанным с приватизацией государственного имущества и принудительным отчуждением имущества для государственных нужд;

2. по спорам, предметом которых являются недвижимое имущество, если такое имущество находится на территории РФ, или права на него;

\footnotetext{
${ }^{15}$ См. об этом более подробно: Муранов А.И. Компетенция судов общей юрисдикции рассматривать предпринимательские споры с участием иностранных лиц в свете нового АПК РФ // Московский журнал международного права. 2002. № 3; Мусин B.A. Некоторые особенности участия в арбитражном процессе иностранных лиц // Российский ежегодник гражданского и арбитражного процесса, 2002-2003. № 2. СПб., 2004; Харсонцев А.И. Компетенция арбитражных судов по рассмотрению дел с участием иностранных лиц. Екатеринбург, 2002.
}

3. по спорам, связанным с регистрацией или выдачей патентов, регистрацией и выдачей свидетельств на товарные знаки, промышленные образцы, полезные модели или регистрацией других прав на результаты интеллектуальной деятельности, которые требуют регистрации или выдачи патента либо свидетельства в РФ;

4. по спорам о признании недействительными записей в государственные реестры (регистры, кадастры), произведенных компетентным органом РФ, ведущим такой реестр (регистр, кадастр);

5. по спорам, связанным с учреждением, ликвидацией или регистрацией на территории РФ юридических лиц и индивидуальных предпринимателей, а также с оспариванием решений органов этих юридических лиц (п. 1 ст. 248 АПК РФ).

В исключительной компетенции арбитражных судов России находятся также дела с участием иностранных лиц, возникающие из административных и иных публичных правоотношений (п. 2 ст. 248 АПК РФ). Таким образом, данная статья закрепляет исключительную компетенцию российских арбитражных судов по рассмотрению международных коммерческих споров определенной категории, что следует отличать от исключительной компетенции российского арбитражного суда по рассмотрению конкретного спора, возникшего в результате заключения пророгационного соглашения между спорящими сторонами.

Правила о договорной подсудности в отношении российских арбитражных судов закреплены в ст. 249 АПК РФ. Согласно содержащимся в ней нормам в случае, если стороны, хотя бы одна из которых является иностранным лицом, заключили соглашение, в котором определили, что арбитражный суд России обладает компетенцией по рассмотрению возникшего или могущего возникнуть спора, связанного с осуществлением ими предпринимательской и иной экономической деятельности, арбитражный суд России будет обладать исключительной компетенцией по рассмотрению данного спора при условии, что такое соглашение не изменяет исключительную компетенцию иностранного суда. Соглашение об определении компетенции должно быть заключено в письменной форме (п. 1-2 ст. 249 
АПК РФ ${ }^{16}$. Таким образом, пророгационное соглашение означает договоренность между спорящими сторонами - сторонами спорного правоотношения (потенциальными истцом и ответчиком) о передаче спора на разрешение в суд какого-либо государства. Такое соглашение выступает как правовая форма реализации норм о договорной подсудности, содержащихся во внутригосударственном праве.

В российском процессуальном законодательстве этому вопросу посвящены ст. 249 АПК РФ и ст. 404 ГПК РФ, причем формулировка заголовка ст. 404 ГПК РФ «Договорная подсудность дел с участием иностранных лиц» значительно лучше формулировки заголовка ст. 249 АПК РФ «Соглашение об определении компетенции арбитражных судов в РФ», ибо позволяет четко разграничить, во-первых, виды подсудности - общую (ст. 247 АПК РФ и ст. 402 ГПК РФ), исключительную (ст. 248 АПК РФ и ст. 403 ГПК РФ) и договорную (ст. 249 АПК РФ и ст. 404 ГПК РФ), а во-вторых, понятие пророгационного соглашения как способа определения подсудности в форме реализации договорной подсудности от понятия самой подсудности как комплекса правил по установлению компетенции того или иного государственного суда. В завершении данного вопроса необходимо еще раз акцентировать внимание на том, что пророгационное соглашение может изменить лишь правила определения общей подсудности, но никогда не исключительной под угрозой признания его юридически недействительным, и в этом контексте договорную подсудность можно рассматривать как измененную соглашением спорящих сторон общую подсудность ${ }^{17}$.

Необходимо отметить, что основным принципом, регулирующим юрисдикционные вопросы с иностранным элементом, выступает местонахождение юридического или физического лицаответчика, что бесспорно отражено в российском процессуальном законодательстве (п. 1(1) ст. 247

\footnotetext{
${ }^{16}$ См.: Монастырский Ю.Э. Основные особенности пророгационных соглашений в Российской Федерации // Московский журнал международного права. 2002. № 2. С. 174-185.

${ }^{17}$ См. об этом более подробно: Шебанова Н.А. Процессуальные особенности рассмотрения дел сучастием иностранных лицв арбитражных судах Российской Федерации // Богуславский М.M., Светланов А.Г. (ред.) Международное частное право: современная практика: Сборник статей. М., 2000. С. 290-299.
}

АПК РФ и п. 2 ст. 402 ГПК РФ). Вместе с тем АПК РФ содержит неординарную новеллу в качестве критерия для установления юрисдикции российского арбитражного суда, а именно, наличие тесной связи спорного правоотношения с территорией России (п. 1(10) ст. 247 АПК РФ). Такого критерия нет в процессуальном законодательстве ни одного государства, так как категория «тесной связи» служит в качестве коллизионной привязки лишь в отношении выбора применимого материального права и не может служить таковой при выборе юрисдикционного органа ${ }^{18}$.

Это связано с тем, что в основу норм, позволяющих выбрать последний, положены фактические обстоятельства, позволяющие однозначно связать российский арбитражный суд и спор, который предполагается передать на его рассмотрение (например, спор возник из отношений, связанных с обращением ценных бумаг, выпуск которых имел место на территории России - п. 1(7) ст. 247 АПК РФ; орган управления, филиал или представительство иностранного лица находится на территории РФ - п. 1(2) ст. 247 АПК РФ). Категория же «тесной связи» не позволяет однозначно выбрать российский арбитражный суд в качестве юрисдикционного органа по разрешению спора, ибо связь спорного правоотношения с территорией России сама нуждается в определении и, кроме того, критерии такого определения с неизбежностью несут на себе отпечаток многовариантности и сами нуждается в согласованном выборе. Таким образом, рассмотренную новеллу АПК РФ вряд ли можно считать удачной.

Еще один важный вопрос затрагивается нормами процессуального законодательства, а именно конфликт юрисдикций (конкуренция юрисдикций), который означает наличие одновременно ведущихся в разных странах судебных разбирательств по одному и тому же предмету, по тем же основаниям и между теми же лицами. В науке МЧП конфликт юрисдикций

\footnotetext{
${ }^{18}$ См. об этом более подробно: Игнатенко Г.В. Международноправовые аспекты взаимодействия материальных и процессуальных норм в АПК и ГПК РФ // Московский журнал международного права. 2003. № 1; Лисииьлн-Светланов А.Г. К вопросу о выборе права и выборе юрисдикции во внешнеэкономических контрактах // Комаров А.С. (ред.) Международный коммерческий арбитраж: современные проблемы и решения: Сборник статей. М., 2007.
} 
получил название «принцип lis alibi pendens».

Поскольку каждое государство самостоятельно устанавливает пределы компетенции своих судов при рассмотрении частноправовых дел с иностранным элементом, именно здесь заложена основа для потенциально возможного конфликта юрисдикций, который бывает двух видов - отрицательный и положительный. Отрицательный конфликт возникает, когда два и более государства отвергают подсудность определенного дела своим судебным органам; положительный конфликт имеет место, когда два и более государства претендуют на подсудность данного дела своим национальным судам.

Термин «конфликт юрисдикций» в данном случае имеет иное значение, чем термин «конфликт законов». В случае конфликта законов суд определяет, право какого государства подлежит применению в данном конкретном случае, в случае же конфликта юрисдикций речь идет о принципах, посредством которых государство устанавливает пределы только собственной юрисдикции. Наилучшим способом разрешения конфликта юрисдикций или, иначе говоря, «столкновения» процессуальных законов двух и более государств, компетентных в силу норм внутреннего законодательства разрешить возникший спор, является создание общих правил о международной судебной юрисдикции посредством заключения международных договоров.

В российском законодательстве процессуальные последствия рассмотрения судом иностранного государства дела по спору между теми же лицами, о том же предмете и по тем же основаниям регулируются ст. 252 АПК РФ и ст. 406 ГПК РФ. Согласно ст. 252 АПК РФ арбитражный суд России оставляет иск без рассмотрения, если в производстве иностранного суда находится на рассмотрении дело по спору между теми же лицами, о том же предмете и по тем же основаниям, при условии, что рассмотрение данного дела не относится к исключительной компетенции арбитражного суда России. Арбитражный суд России прекращает производство по делу, если имеется вступившее в законную силу решение иностранного суда, принятое по спору между теми же лицами, о том же предмете и по тем же основаниям, при условии, что рассмотрение данного дела не относится к исключительной компе- тенции арбитражного суда России или указанное решение не подлежит признанию и приведению в исполнение в России.

Несколько иные нормы, касающиеся процессуальных последствий рассмотрения дел иностранным судом, закреплены в ст. 406 ГПК РФ. Согласно ее требованиям суд общей юрисдикции России отказывает в принятии искового заявления к производству или прекращает производство по делу, если имеется решение суда по спору между теми же сторонами, о том же предмете и по тем же основаниям, принятое иностранным судом, с которым имеется международный договор РФ, предусматривающий взаимное признание и исполнение решений суда. Суд России возвращает исковое заявление или оставляет заявление без рассмотрения, если в иностранном суде, решение которого подлежит признанию или исполнению на территории РФ, ранее было возбуждено дело по спору между теми же сторонами, о том же предмете и по тем же основаниям.

Из анализа вышеприведенного текста следует, что нормы АПК РФ и ГПК РФ разграничивают ситуации, когда иностранное судебное решение уже вынесено либо когда тождественное дело еще находится на рассмотрении в иностранном суде. В первом случае российские суды общей юрисдикции отказывают в принятии искового заявления к производству или прекращают производство по делу, и при этом с соответствующим иностранным государством имеется в наличии международный договор РФ, предусматривающий взаимное признание и исполнение решений суда (ч. 1 ст. 406 ГПК РФ). Ч. 2 ст. 252 АПК РФ регламентирует подобную ситуацию иначе. Вопервых, арбитражные суды в случае наличия иностранного судебного решения по тождественному делу обязаны принять заявление к производству, а затем в дальнейшем прекратить производство по делу. Это обусловлено тем, что в АПК РФ, в отличие от ГПК РФ, отсутствует институт отказа в принятии заявления.

Во-вторых, АПК РФ прямо говорит о том, что иностранное судебное решение должно вступить в законную силу. Ст. 406 ГПК РФ гласит лишь о том, что иностранное судебное решение должно быть в наличии. То, что оно должно вступить в законную силу, логически вытекает из системного толкования ст. 406 и 412 ГПК РФ, в соответствии с 
которыми иностранное судебное решение, не вступившее в законную силу, не подлежит исполнению на территории Российской Федерации, а в случае, если за рубежом еще идет судебный процесс по тождественному делу (в том числе, когда судебное решение уже вынесено, но еще не вступило в законную силу), суд общей юрисдикции обязан возвратить исковое заявление или оставить его без рассмотрения. Вместе с тем необходимо отметить, что редакция ст. 252 АПК РФ, напрямую указывающая на необходимость вступления иностранного судебного решения в законную силу, является в этой части более удачной.

В-третьих, другим существенным различием является то, что ст. 406 ГПК РФ указывает обязательное условие применения принципа lis alibi pendens - наличие международного договора РФ, предусматривающего взаимное признание и исполнение решений суда. В противном случае, исходя из строгого толкования норм ГПК РФ, иностранное судебное решение не должно признаваться и исполняться на территории Российской Федерации, и следовательно, даже при наличии такого решения суд общей юрисдикции обязан рассмотреть гражданское дело по существу. Арбитражные суды в этой ситуации должны действовать иначе: в соответствии со ст. 241, 244 и 252 АПК РФ иностранные судебные решения признаются, а принцип lis alibi pendens применяется не только в случаях, когда это предусмотрено международным договором РФ, но и если этого требует федеральный закон. В России принято несколько федеральных законов, указывающих, что иностранные судебные решения подлежат признанию и исполнению не только при наличии международного договора, но и в силу принципа взаимности.

Наконец, в-четвертых, различие заключается в том, что в соответствии со ст. 252 АПК РФ арбитражный суд не прекращает производство по делу, если иностранное судебное решение вынесено по вопросу, относящемуся к исключительной компетенции арбитражного суда РФ. Данное правило текстуально не закреплено в ст. 406 ГПК РФ, однако оно логически вытекает из ч. 3 ст. 412 и ст. 414 , в соответствии с которыми вступившее в законную силу иностранное судебное решение не признается на территории РФ, если рассмотрение тождественного дела относится к исключитель- ной подсудности судов в Российской Федерации. Суд общей юрисдикции в этом случае продолжает рассматривать дело по существу.

Вторым аспектом принципа lis alibi pendens является ситуация, когда иностранное судебное решение еще не вступило в законную силу, однако судебный процесс по одному и тому же гражданскому уже идет параллельно в разных государствах. И в регламентации этого вопроса процессуальные кодексы также расходятся. Суд общей юрисдикции обязан возвратить исковое заявление либо оставить заявление без рассмотрения, если в иностранном суде ранее было возбуждено дело по спору между теми же сторонами, о том же предмете и по тем же основаниям (ч. 2 ст. 406 ГПК РФ). Ситуацию, когда российский суд возбудил гражданское дело раньше, чем в иностранном суде, ГПК РФ не регламентирует. Очевидно, в этом случае суд общей юрисдикции просто продолжит рассмотрение дела по существу. Ч. 1 ст. 252 АПК РФ регулирует эту ситуацию несколько иначе. Во-первых, арбитражный суд в подобном случае обязан оставить заявление без рассмотрения. Возвращать заявление, в отличие от судов общей юрисдикции, он не вправе. Из этого правила есть только одно исключение - если дело относится к исключительной компетенции российских арбитражных судов, то заявление без рассмотрения не оставляется, и арбитражный суд продолжает производство по делу в общем порядке.

Второе различие заключается в том, что в соответствии со ст. 252 АПК РФ не имеет никакого правового значения, какой суд - российский или иностранный - возбудил дело раньше. Арбитражный суд обязан оставить заявление без рассмотрения, если в производстве иностранного суда находится на рассмотрении дело по спору между теми же лицами, о том же предмете и по тем же основаниям (то есть, исходя из буквального толкования этой нормы - во всех случаях, даже если в России производство по делу началось раньше) $)^{19}$.

Сходные с российскими принципы установления судебной юрисдикции положены в

\footnotetext{
${ }^{19}$ См.: Мамаев А.А. Одновременное рассмотрение гражданского дела судами разных государств (lis alibi pendens) // Внешнеторговое право. 2006. № 2. С. 2-3.
} 
основу Минской конвенции, которая по своей юридической природе является многосторонним региональным международным договором, устанавливающим основные принципы обращения граждан и юридических лиц одного Договаривающейся стороны в суды на территории другой Договаривающейся стороны. Наиболее важными из конвенционных принципов определения международной подсудности являются принцип национального режима, закрепленный в ст. 1, и принцип разграничения территориальной подсудности на основании критерия местожительства ответчика, закрепленный в ст. 20.

В соответствии со ст. 1 Минской конвенции граждане каждой из Договаривающихся сторон, а также лица, проживающие на ее территории, пользуются на территориях всех других Договаривающихся сторон в отношении своих личных и имущественных прав такой же правовой защитой, как и собственные граждане данной Договаривающейся стороны. Граждане каждой из Договаривающихся сторон, а также другие лица, проживающие на ее территории, имеют право свободно и беспрепятственно обращаться в суды других Договаривающихся сторон, к компетенции которых относятся гражданские и семейные дела (далее - учреждения юстиции), могут выступать в них, подавать ходатайства, предъявлять иски и осуществлять иные процессуальные действия на тех же условиях, что и граждане данной Договаривающейся стороны. Положения Минской конвенции применяются также к юридическим лицам, созданным в соответствии с законодательством Договаривающихся сторон.

В соответствии со ст. 20 Минской конвенции иски к лицам, имеющим местожительство на территории одной из Договаривающихся сторон, предъявляются независимо от их гражданства в суды этой Договаривающейся стороны, а иски к юридическим лицам предъявляются в суды Договаривающейся стороны, на территории которой находится орган управления юридического лица, его представительство либо филиал. Если в деле участвуют несколько ответчиков, имеющих местожительство (местонахождение) на территориях разных Договаривающихся сторон, спор рассматривается по местожительству (местонахождению) любого ответчика по выбору истца.
Суды Договаривающейся стороны компетентны также в случаях, когда на ее территории:

- осуществляется торговля, промышленная или иная хозяйственная деятельность предприятия (филиала) ответчика;

- исполнено или должно быть полностью или частично исполнено обязательство из договора, являющегося предметом спора;

- имеет постоянное местожительство или местонахождение истец по иску о защите чести, достоинства и деловой репутации.

По искам о праве собственности и иных вещных правах на недвижимое имущество исключительно компетентны суды по месту нахождения имущества. Иски к перевозчикам, вытекающие из договоров перевозки грузов, пассажиров и багажа, предъявляются по месту нахождения управления транспортной организации, к которой в установленном порядке была предъявлена претензия. Два последних основания представляют собой случаи установления исключительной юрисдикции суда той или иной Договаривающейся стороны, которые не могут быть изменены по договоренности сторон и, соответственно, не могут быть предметом пророгационного соглашения. Вместе с тем Минская конвенция регулирует и вопросы договорной подсудности. В соответствии с положениями ст. 21 суды Договаривающихся сторон могут рассматривать дела и в тех случаях, если имеется письменное соглашение сторон о передаче спора этим судам. При этом исключительная компетенция, вытекающая из ст. 29 Минской конвенции и других норм, а также из внутреннего законодательства соответствующей Договаривающейся стороны, не может быть изменена соглашением сторон. При наличии соглашения о передаче спора суд по заявлению ответчика прекращает производство по делу.

Минская конвенция не обошла своим вниманием и вопрос о конфликте юрисдикций. Ст. 22 «Взаимосвязь судебных процессов» определяет, что в случае возбуждения производства по делу между теми же сторонами, о том же предмете и по тем же основаниям в судах двух Договаривающихся сторон, компетентных в соответствии с настоящей конвенцией, суд, возбудивший дело позднее, прекращает производство. Встречный иск и требование о зачете, 
вытекающие из того же правоотношения, что и основной иск, подлежат рассмотрению в суде, который рассматривает основной иск ${ }^{20}$.

Киевское соглашение СНГ 1992 г. о порядке разрешения споров, связанных с осуществлением хозяйственной деятельности ${ }^{21}$ (далее - Киевское соглашение) регулирует вопросы разрешения дел, вытекающих из договорных и иных гражданскоправовых отношений между хозяйствующими субъектами, из их отношений с государственными и иными органами, а также исполнения решений по ним (ст. 1). Под хозяйствующими субъектами понимаются предприятия, их объединения, организации любых организационноправовых форм, а также граждане, обладающие статусом предпринимателя в соответствии с законодательством, действующим на территории государств - участников СНГ, и их объединения (ст. 2). Хозяйствующие субъекты каждого из государств - участников СНГ пользуются на территории другого государства-участника СНГ правовой и судебной защитой своих имущественных прав и законных интересов, равной с хозяйствующими субъектами данного государства. Хозяйствующие субъекты каждого государства - участника СНГ имеют на территории других государств - участников СНГ право беспрепятственно обращаться в суды, арбитражные (хозяйственные) суды, третейские суды и другие органы, к компетенции которых относится разрешение вышеуказанных дел (в дальнейшем - компетентные суды), могут выступать в них, возбуждать ходатайства, предъявлять иски и осуществлять иные процессуальные действия (ст. 3).

Компетентный суд государства - участника СНГ вправе рассматривать гражданско-правовые споры экономического характера, если на территории данного государства - участника СНГ:

а) ответчик имел постоянное место жительства или место нахождения на день предъявления иска. Если в деле участвуют несколько ответчиков,

\footnotetext{
${ }^{20}$ См. об этом более подробно: Светланов А.Г. Проблемы взаимосвязи судопроизводства в международном гражданском процессе // Государство и право. 2002. № 10.

${ }^{21}$ Информационный вестник Совета глав государств и Совета глав правительств СНГ «Содружество». 1992. № 4. Киевское соглашение вступило в силу 19 декабря 1992 г. После ратификации для России оно вступило в силу 19 декабря 1992 г.
}

находящихся на территории разных государств участников СНГ, спор рассматривается по месту нахождения любого ответчика по выбору истца;

б) осуществляется торговая, промышленная или иная хозяйственная деятельность предприятия (филиала) ответчика;

в) исполнено или должно быть полностью или частично исполнено обязательство из договора, являющееся предметом спора;

г) имело место действие или иное обстоятельство, послужившее основанием для требования о возмещении вреда;

д) имеет постоянное место жительства или место нахождения истец по иску о защите деловой репутации;

е) находится контрагент - поставщик, подрядчик или оказывающий услуги (выполняющий работы), а спор касается заключения, изменения и расторжения договоров.

Компетентные суды государств - участников СНГ рассматривают дела и в других случаях, если об этом имеется письменное соглашение сторон о передаче спора этому суду. При наличии такого соглашения суд другого государства - участника СНГ прекращает производство дел по заявлению ответчика, если такое заявление сделано до принятия решения по делу. Иски субъектов хозяйствования о праве собственности на недвижимое имущество рассматриваются исключительно судом государства - участника СНГ, на территории которого находится имущество. Дела о признании недействительными полностью или частично не имеющих нормативного характера актов государственных и иных органов, а также о возмещении убытков, причиненных хозяйствующим субъектам такими актами или возникших вследствие ненадлежащего исполнения указанными органами своих обязанностей по отношению к хозяйствующим субъектам, рассматриваются исключительно судом государства участника СНГ по месту нахождения указанного органа. Исключительная компетенция судов не может быть изменена соглашением сторон. Встречный иск и требование о зачете, вытекающие из того же правоотношения, что и основной иск, подлежат рассмотрению в том суде, который рассматривает основной иск (ст. 4).

Следует отдельно подчеркнуть соотношение российского процессуального законодательства, 
норм Минской конвенции и Киевского соглашения как многосторонних международных договоров, участницей которых является Россия, применительно к определению международной судебной юрисдикции. Общее правило заключается в следующем: на основании принципов МЧП, если встает вопрос об установлении юрисдикции российского суда по спору с участием физических или юридических лиц любого из государств - членов СНГ, то должны применяться не нормы АПК РФ или ГПК РФ, а нормы Минской конвенции или Киевского соглашения в зависимости от характера рассматриваемого спора. Экономические споры между хозяйствующими субъектами подпадают под действие Киевского соглашения, иные частноправовые споры - под регулирование Минской конвенции.

Интеграционные процессы, протекающие в европейском экономическом и политическом пространстве, привели к унификации норм международного процессуального права. Важнейшим документом в этой области выступает Луганская конвенция 2007 г. о юрисдикции и приведении в исполнение судебных решений по гражданским и торговым делам ${ }^{22}$ (далее - Луганская конвенция), заключенная государствами - членами ЕС и государствами - членами ЕАСТ, которая представляет собой обширный договор, состоящий из 79 статей и включающий 3 протокола, а также 9 приложений. Луганская конвенция применяется к гражданским и торговым делам независимо от природы суда, их рассматривающего, однако она не распространяется на налоговые, таможенные и административные споры.

Кроме этого, Луганская конвенция не регулирует правовой статус и правосубъектность физических лиц; право собственности, возникающее из брачно-семейных отношений; наследственные отношения и правопреемство; банкротство (неплатежеспособность) юридических лиц и другие аналогичные процедуры; социальное обеспечение; арбитраж (ст. 1). В силу данной конвенции принципы установления судебной юрисдикции по международным частноправовым спорам получили еще более широкое распространение, так как помимо

${ }^{22}$ Official Journal of the European Union. L 147. 10.06.2009. P. 5-147. Луганская конвенция вступила в силу 01 января 2011 г. Россия в ней не участвует. западноевропейских государств, не участвующих в ЕС, к Луганской конвенции могут присоединиться и страны Центральной и Восточной Европы.

Основным принципомустановления юрисдикции суда при разрешении международного частноправового спора выступает местонахождение ответчика. Гражданство физического лица или государственная принадлежность юридического лица никакого значения не имеют (п. 2 ст. 2). Отказ при определении юрисдикции от принципа домицилия ответчика возможен лишь в специально оговоренных случаях, наиболее важные из которых перечислены в ст. 5-21. Остановимся на них более подробно. Луганская конвенция предусматривает, что лицо, домицилированное на территории одного Договаривающегося государства, может быть привлечено к суду на территории другого Договаривающегося государства:

1. по спорам, относящимся к контрактам - по месту выполнения основного принципиального обязательства (the place of performance of the obligation in question). Под местом выполнения основного принципиального обязательства Луганская конвенция понимает:

- $\quad$ в случае купли-продажи товаров - место в Договаривающемся государстве, где, согласно контракту, товары поставлены или должны быть поставлены;

- в случае оказания услуг - место в Договаривающемся государстве, где, согласно контракту, услуги оказаны или должны быть оказаны (п. 1 ст. 5);

2. по спорам, относящимся к деликтам - по месту наступления или вероятного наступления вредоносного события (harmful event) (п. 3 ст. 5);

3. по спорам, связанным с деятельностью филиала, агентства или иного учреждения - по месту их нахождения (п. 5 ст. 5);

4. по спорам, связанным со страхованием, страховщик, домицилированный в Договаривающемся государстве, может быть привлечен к суду:

- $\quad$ на территории Договаривающегося государства, где он домицилирован;

- на территории другого Договаривающегося государства, где домицилирован 
истец, если им выступает держатель страхового полиса (страхователь, застрахованный) или бенефициар;

- $\quad$ на территории Договаривающегося государства, где возбуждено судопроизводство против главного состраховщика, а он является одним из состраховщиков (п. 1 ст. 9);

5. по спорам, связанным с потребительскими договорами, потребитель (consumer) может начать судопроизводство против своего контрагента в суде Договаривающегося государства, где домицилирован контрагент, либо в суде Договаривающегося государства, где домицилирован потребитель. Контрагент может предъявить иск к потребителю только в суде Договаривающегося государства, где домицилирован потребитель (п. 1-2 ст. 16);

6. по трудовым спорам, связанным с индивидуальными трудовыми контрактами, работник (employee) может начать судопроизводство против своего работодателя (employer) в суде того Договаривающегося государства, где работник обычно выполняет или выполнял свои трудовые обязанности, либо если работник не выполняет или не выполнял свои трудовые обязанности на территории одного государства, в суде того Договаривающегося государства, где ведется или велась деятельность, которой занимался работник. Работодатель может предъявить иск к работнику только в суде того Договаривающегося государства, где домицилирован работник (п. 1-2 ст. 19; п. 1 ст. 20).

Следует отметить, что ст. 2 Луганской конвенции закрепляет правило универсальной юрисдикции, тогда как ст. 5-21 регулируют правила специальной юрисдикции. По отношению к универсальной специальная юрисдикция предлагает иные пути к определению надлежащей судебной юрисдикции и вследствие этого вполне может рассматриваться как альтернативная. Совершенно очевидно, что правила определения последней носят строго ограниченный характер и четко формулируются в правовом акте, а нормы, закрепляющие такие правила, выступают как специальные по отношению к общим нормам, регулирующим универсальную юрисдикцию. Таким образом, наряду с классификацией юрисдикции на общую, исключительную и договорную по критерию порядка ее установления можно предложить и иную классификацию юрисдикции на универсальную и альтернативную по критерию характера спорного правоотношения ${ }^{23}$.

Несмотря на достаточно ясные формулировки коллизионных норм ст. 5-21 Луганской конвенции, сразу же возникают вопросы о толковании отдельных терминов, в них содержащихся. Что понимать под выражениями «основное принципиальное обязательство» и «вредоносное событие»? Каковы конститутивные признаки понятий филиала, агентства или иного учреждения? Ответ на эти вопросы был дан Судом ЕС при толковании Брюссельской конвенции 1968 г. с аналогичным названием, которая действовала на территории государств - членов Европейского Союза вплоть до принятия Регламента ЕС № 44/2001 «О юрисдикции, признании и приведении в исполнение судебных решений по гражданским и торговым делам» от 22 декабря 2000 г. (далее - Регламент Брюссель I), заменившего Брюссельскую конвенцию 1968 г. в отношениях между государствами - членами Европейского Союза 24 .

Вопросы, на которые должен был дать ответ Суд $\mathrm{EC}$, формулировались апелляционным судом того государства, суд которого возбудил производство по делу. Суд ЕС был не вправе выходить за пределы сформулированных вопросов по существу и был обязан отвечать только на них. К моменту принятия вышеупомянутого Регламента EC Суд ЕC вынес около сотни решений, направ-

\footnotetext{
${ }^{23}$ См.: Папкова О.А. Международная специальная юрисдикция (альтернативная подсудность) в гражданском процессе государств - участников Европейского Союза // Вестник Московского университета. Серия 11 «Право». 2001. № 2. C. $58-59$.

${ }^{24}$ Луганская конвенция 2007 г. заменила аналогичную конвенцию 1988 г., состоявшую из 68 статей и включавшую 3 протокола. Принятие новой Луганской конвенции было обусловлено изменениями в международном процессуальном праве ЕС, приведшими к замене Брюссельской конвенции 1968 г. Регламентом Брюссель І. В научной литературе Брюссельская конвенция 1968 г. и Луганская конвенция 1988 г. получили название «параллельных» конвенций. См. об этом более подробно: Елисеев Н.Г. История возникновения и общая характеристика Брюссельской и Луганской конвенций о подсудности и исполнении судебных постановлений по гражданским и торговым делам // Московский журнал международного права. 2002. № 3. С. 81-95.
} 
ленных на толкование тех или иных положений Брюссельской конвенции. При этом Суд ЕС использовал два возможных пути толкования. Первый из них заключался в том, что толкование основывалось на нормах внутригосударственного (национального) права. Однако в силу объективно сложившихся различий в правовых системах мира и, следовательно, в национальном праве разных государств, данный путь вряд ли мог привести к единообразному толкованию правовых терминов. Второй путь предполагал автономное толкование положений конвенции самим Судом ЕС, исходя из целей и духа конвенции. В этом случае автономно сформулированные понятия одинаково применялись во всех государствах участниках Брюссельской конвенции, что создавало унификацию не только национального права, но и правоприменительной практики.

Анализируя принципы установления юрисдикции в соответствии с нормами Луганской конвенции, нельзя обойти вниманием еще три аспекта - установление исключительной юрисдикции, заключение пророгационных соглашений и конфликт (конкуренция) юрисдикций. Остановимся на них более подробно. Согласно п. 1-5 ст. 22 Луганской конвенции независимо от домицилия ответчика исключительной юрисдикцией обладают:

1) по спорам, предметом которых выступают права собственности на недвижимое имущество или аренды недвижимого имущества, суды того Договаривающегося государства, где находится недвижимое имущество;

2) по спорам, предметом которых выступает действительность создания или ликвидации компаний или иных юридических лиц, а также ассоциаций физических или юридических лиц, либо действительность решений их органов, суды того Договаривающегося государства, на территории которого находится компания, юридическое лицо или ассоциация (company, legal person or association has its legal seat);

3) по спорам, предметом которых выступает действительность записей в государственных peестрах (entries in public registers), суды того Договаривающегося государства, на территории которого ведется реестр (register is kept);

4) по спорам, касающимся регистрации или действительности прав на патенты, товарные знаки или сходных прав, которые должны быть депонированы или зарегистрированы, суды того Договаривающегося государства, где депонирование или регистрация были произведены;

5) по спорам, касающимся приведения в исполнение судебных решений, суды того Договаривающегося государства, где судебное решение было приведено в исполнение или должно быть приведено в исполнение.

В соответствии с п. 1-2 ст. 23 Луганской конвенции, если стороны, как минимум одна их которых домицилирована в Договаривающемся государстве, заключили соглашение о том, что суд или суды Договаривающегося государства имеют юрисдикцию разрешить любой спор, возникший или могущий возникнуть из отдельного правоотношения, то только данный суд или суды обладают юрисдикцией. Такая юрисдикция является исключительной, если стороны не договорились об ином. Пророгационное соглашение должно быть:

- заключено в письменной форме или должно подтверждаться письменными доказательствами;

- $\quad$ заключено в форме, соответствующей практике, которая сложилась в отношениях между сторонами;

- заключено в форме, соответствующей обычаям международной торговли, о которых стороны знали и которые хорошо известны и регулярно соблюдаются сторонами контрактов данного типа.

Любое электронное взаимодействие сторон, обеспечивающее фиксацию пророгационного соглашения на материальном носителе (durable record of the agreement), должно приравниваться к письменной форме.

Конфликт юрисдикций (lis pendens) означает, что дело по одному и тому же спору рассматривается в судах более чем одного государства. Параллельные процессы таят в себе угрозу вынесения нескольких решений, что может лишить эффективности приведение их в исполнение, поэтому законодательно государства стремятся предотвратить возникновение такой ситуации. Ст. 27 Луганской конвенции говорит, что в случае возбуждения гражданского судопроизводства по тому же основанию и между теми же сторонами в нескольких судах разных Договаривающихся 
государств суд, первым принявший дело к производству, может считать свою юрисдикцию правомерно установленной. Остальные суды должны приостановить судебный процесс, а затем и прекратить производство по делу. Когда юрисдикция суда, первым принявшего дело к производству, окончательно установлена, любой иной суд, принявший дело к производству и приостановивший его, обязан прекратить производство по делу (п. 1-2). Суд считается принявшим дело к производству, когда им принят документ о возбуждении гражданского судопроизводства (the document instituting the proceeding is lodged with the court). При этом истец впоследствии должен предпринять все требуемые действия по надлежащему извещению ответчика о возбуждении против него гражданского судопроизводства (service effected on the defendant) (п. 1 ст. 30).

В завершении вопроса о конфликте юрисдикций хотелось бы остановиться на соотношении категорий «ограничение юрисдикций» и «разграничение юрисдикций», так как последняя имеет непосредственное отношение к проблеме устранения конфликта юрисдикций в международном гражданском процессе. Несомненно, что критерием для выделения двух вышеупомянутых категорий выступает цель, которую преследует законодатель при формулировании соответствующих правил. Цель ограничения юрисдикции - установление своего рода международно-правового барьера на пути ее возможного расширения. Ограничения адресованы каждому государству в отдельности или нескольким государствам на основании заключенного ими договора. Ограничения обозначают конкретному государству, до каких пределов оно может расширить свою юрисдикцию, и устанавливаются путем согласования волеизъявления государств. Классическим примером ограничения юрисдикции государства выступают дипломатические привилегии и иммунитеты.

Цель разграничения юрисдикции абсолютно иная и состоит в том, чтобы устранить ситуации совмещения или перекрытия юрисдикций разных государств. Потребность в таком разграничении появляется тогда, когда несколько государств на равных основаниях могут претендовать на установление и осуществление своей юрисдикции в отношении определенных лиц, объектов и видов деятельности, не выходя за пределы, определяемые международным правом. Ограничения в подобных ситуациях не препятствуют тому, что юрисдикции государств перекрывают друг друга. Для воспрепятствования этому требуется именно их разграничение. Не исключено, что нормы права, предотвращая конкуренцию юрисдикций государств путем их разграничения, могут одновременно выполнять и другую задачу - устанавливать их взаимные ограничения, но, тем не менее, всегда следует помнить о различных целях, которые преследуют ограничение и разграничение юрисдикций государств ${ }^{25}$.

\section{§ 2. Международная судебная юрисдикция в английском, американском и французском праве}

Юрисдикция английских судов по делам с участием иностранных юридических и физических лиц определена в английском общем праве, основанном на судебных прецедентах, а также в статутном праве, объединяющем законодательные акты. Юрисдикция английского суда над иностранными физическими лицами может быть установлена только в том случае, если они находятся на территории Великобритании (Adams v. Cape Industries (1990)) ${ }^{26}$. Такое личное присутствие на британской территории должно быть добровольным, а не вызванным обманом, шантажом или иными злонамеренными действиями. При этом не имеет значения длительность такого пребывания: оно может быть как постоянным, так и временным. Вторым слагаемым правомерного установления юрисдикции английского суда над физическими лицами-иностранцами выступает надлежащее вручение судебной повестки и судебного документа о возбуждении производства по делу (writ or claim form).

Именно этот документ свидетельствует о начале гражданского судопроизводства в английском суде против ответчика и тем самым информирует его об этом. Вручение такого судебного

\footnotetext{
${ }^{25}$ См.: Черниченко О.С. Устранение конкуренции юрисдикций государств: внутригосударственные и международно-правовые подходы // Московский журнал международного права. 2002. № 4. C. 238-239.

${ }^{26}$ Adams v. Cape Industries case [1990] 2 W.L.R. 657 (C.A.).
} 
документа признается надлежащим, если он персонально вручен ответчику истцом или агентом (представителем) истца. Кроме того, истец может послать данный судебный документ по почте или вложить его в почтовый ящик в запечатанном конверте по обычному или последнему известному адресу ответчика, дав письменную присягу о том, что судебный документ достигнет ответчика в течение семи дней после отправления его по почте или вложения в почтовый ящик (Barclays Bank of Swaziland Ltd. v. Hahn (1989)) ${ }^{27}$.

Юрисдикция английского суда над иностранными юридическими лицами может быть установлена в том случае, если они находятся на территории Англии. В соответствии с общим правом под нахождением на британской территории имеются в виду инкорпорация (регистрация) юридического лица в Англии либо ведение им бизнеса на территории Англии. Последнее предполагает наличие определенного места ведения бизнеса, содержащегося за счет его средств, а также (если бизнес ведется через агента) наличие более чем минимального периода времени, в течение которого осуществлялась деловая активность агента (Adams v. Cape Industries). Юрисдикция английского суда может быть установлена и в том случае, если иностранное физическое или юридическое лицо не находится на территории Англии и не имеет здесь центра деловой активности. В этом случае юрисдикция будет установлена по усмотрению самого суда, что входит в разряд его дискреционных полномочий.

Юрисдикция американских судов по делам с участием иностранных физических и юридических лиц определена в американском общем праве. Примером может служить решение Верховного Суда США по делу World-Wide Volksvagen Corporation v. Woodson (1980) ${ }^{28}$. Суд указал, что для установления юрисдикции американского суда над юридическими или физическими лицами-нерезидентами необходимо наличие двух факторов: законодательного базиса, содержащего перечень возможных оснований для признания юрисдикции правомерно установленной, а также соблюдения правила о должном процессе (due process clause), закрепленного в Конституции

\footnotetext{
${ }^{27}$ Barclays Bank of Swaziland Ltd. v. Hahn [1989] 1 W.L.R. 506 (H.L.).

${ }^{28}$ U.S. Supreme Court Reports (1980) 62 L Ed 2d p. 497-502.
}

США 1789 г. и в конституциях штатов. Последнее предполагает политическую и юридическую защиту лица от судебного разбирательства, которое нарушает «традиционные понятия честной игры и основательного правосудия».

Юридическим выражением этого конституционного постулата применительно к международному гражданскому процессу выступает доктрина «минимальных контактов». В сущности, она означает, что юридическое или физическое лицо, не являющееся резидентом, может быть ответчиком в американском суде, только если имеют место необходимые минимальные контакты данного лица с той территориальной единицей, где предполагается проведение процесса. При разрешении вопроса о наличии или отсутствии минимальных контактов в каждом конкретном случае американский суд, опираясь на общее право, будет применять два критерия: критерий разумности, позволяющий предотвратить судебное разбирательство в неудобном для ответчика суде, и критерий предвидения, означающий, что ответчик должен заранее предвидеть возможность его привлечения к американскому суду в силу осуществляемой им коммерческой деятельности на территории США.

Таким образом, иностранная торговая компания, осуществляющая продажу своего товара через коммерческого представителя, подлежит юрисдикции либо любого американского суда, если деятельность коммерческого представителя распространяется на всю территорию США, либо суда того штата, на территории которого действует коммерческий представитель. В упомянутом выше споре суд штата Оклахома отверг установление своей юрисдикции над дистрибьюторской фирмой, зарегистрированной в штате Нью-Йорк, на том основании, что ее деятельность распространялась лишь на территории штатов НьюЙорк, Нью-Джерси и Коннектикут, а не Оклахому. В этом случае, по мнению суда, отсутствовали минимальные контакты предполагаемого ответчика со штатом Оклахома. Нелишне отметить, что нахождение, хотя бы и временное, физического лица на территории США и регистрация представительства иностранного юридического лица в США, безусловно, являются достаточными основаниями для признания юрисдикции американского суда правомерно установленной. 
Таким образом, в английском и американском праве компетенция суда по рассмотрению дел с иностранным элементом определяется в рамках понятия «юрисдикция» (jurisdiction). Термин «юрисдикция» означает здесь общее полномочие («физическую власть») ${ }^{29}$ выносить решение по тому или иному делу, предоставленное судам суверенной властью государства, в отношении лиц и имущества, которые находятся на принадлежащей ему территории ${ }^{30}$. Концепция юрисдикции в общем праве (common law) рассматривается в двух аспектах: в позитивном смысле данное понятие имеет вышеназванное значение, то есть полномочие суда выносить решение по тому или иному делу; в негативном смысле оно означает возможность для суда отказаться от осуществления предоставленных ему полномочий.

Отказ от осуществления полномочий обозначается в доктрине общего права термином на латинском языке «forum non conveniens»" Доктрина «forum non conveniens» предоставляет возможность суду, наделенному полномочиями на рассмотрение и разрешение спора по национальному законодательству, признать иностранный суд более подходящим для разбирательства конкретного дела и отказать в принятии его к производству. На практике такой отказ суда от своей юрисдикции последует только после заявления ходатайства ответчика об отклонении иска на основании доктрины «forum non conveniens».

Право Англии использует и другой инструмент под названием «forum conveniens»: не предоставляя полномочий судье prima facie на рассмотрение и разрешение спора, английский законодатель, тем не менее, дает возможность судье in concreto, с учетом особенностей данного дела, принять его к производству, если английский суд окажется более удобным и справедливым для такого разбирательства ${ }^{32}$. «Forum conveniens» и

\footnotetext{
${ }^{29}$ McDonald v. Mabee [1917] 243 U.S.C. P. 90-91.

${ }^{30}$ См.: Bauer $H$. Competence judiciaire internationale des tribunaux civils francais et allemande. Paris, 1965. P. 4; Mann F.A. The Doctrine of Jurisdiction in International Law // Recueil des cours de la Haye, 1964. Vol. I. P. 9 et seq.

${ }^{31}$ См.: Anton A.E. Private International Law. Edinbourg, 1967. P. 90.

${ }^{32}$ См.: Schneider B. Le forum conveniens et le forum non conveniens (en droit ecossais, anglais et americain) // Revue internationale de droit compare. Juillet-septembre 1975. Vol. 27. № 3.
}

«forum non conveniens» являются двумя различными инструментами, имеющими противоположное правовое действие, но объединенными общей идеей: в государствах общего права судья имеет дискреционные полномочия поиска надлежащего суда для данного конкретного дела и определения своей компетенции по его рассмотрению и разрешению.

Как уже было упомянуто выше, согласно традиционным правилам английского судопроизводства юрисдикция английского суда над делом устанавливается в том случае, когда ответчик физически присутствует в границах суверенной территории Англии. Механизм установления подсудности основывается на следующем общем правиле: спор подпадает под юрисдикцию английского суда в случае, если судебная повестка с приказом явиться в суд (writ or claim form) лично вручена ответчику. «Этого достаточно для подчинения его юрисдикции английского суда, даже если он иностранец, находящийся в Англии проездом, и даже, если основание иска не имеет фактической связи с Англией. Ничто другое не является достаточным» ${ }^{33}$. На этом уровне процедуры неважно, подчинится ли получатель документа судебному приказу явиться в английский суд либо проигнорирует данное требование и уедет, например, за границу. В этом случае считается, что ответчик надлежащим образом уведомлен, и английский орган юстиции может рассматривать и разрешать спор.

Издавна признается, что отсутствующий ответчик может подчиниться юрисдикции английского суда и тем самым признать его компетентным рассматривать соответствующее дело: ответчик может, например, поручить адвокатской конторе принять судебную повестку от его имени; подача ответчиком искового заявления наделяет суд компетенцией рассматривать также и встречный иск; ответчик, явившийся в процесс и оспаривающий иск по существу, будет

Р. 605. См. об отдельных аспектах юрисдикции американских судов по международным коммерческим спорам: Барнашев A.B. Экстерриториальная юрисдикция в США: forum non Conveniens // Журнал международного частного права. 1999. № 4. C. 45-54.

${ }^{33}$ См.: Чешир Дж., Норт П. Международное частное право. M., 1982. C. 77. 
считаться подчинившимся юрисдикции суда, но явка в суд исключительно с целью оспорить его компетенцию не означает подчинение этой юрисдикции ${ }^{34}$. Если в странах континентального права можно начать производство в суде, когда он, в соответствии с законом, обладает компетенцией, то в Англии, согласно общему праву, напротив, суд будет иметь юрисдикцию, если истец сумеет во время нахождения ответчика на территории Великобритании вручить ему документ о возбуждении гражданского судопроизводства - судебную повестку (writ or claim form $)^{35}$.

Однако действие принципа, согласно которому судебная юрисдикция основывается лишь на вручении повестки о вызове в суд, иногда ограничивается, несмотря на то, что ответчик был надлежащем образом вызван в суд. Судебная практика определяет эти исключения следующим образом: вопросы, связанные с иностранным недвижимым имуществом, иностранным налогообложением, правами и обязанностями, основанными на иностранном уголовном законе, не будут подсудны английскому суду ${ }^{36}$. В обычном порядке истец имеет право вызвать ответчика в суд, вручив ему судебную повестку, предписывающую явиться в суд (service of the writ or service of the claim form), только тогда, когда последний присутствует на территории Англии. Данное обстоятельство часто мешает истцу реализовать свое требование в английском суде, который, например, в подобных случаях для этого наиболее подходит (например, деликт совершен или договор заключен и нарушен в Англии). Принимая во внимание все эти обстоятельства, закон ввел совершенно новый вид юрисдикции, носящей подразумеваемый характер (assumed character), дающий английскому суду дискреционное право вызвать повестками отсутствующих ответчиков, будь то англичане или иностранцы.

Если потенциальный ответчик реально находится вне юрисдикции Англии, например, в Шотландии или Северной Ирландии, либо вообще за пределами Великобритании,

\footnotetext{
${ }^{34}$ См.: Чешир Дж., Норт П. Указ. соч. С. 85-86.

${ }^{35}$ См.: Schneider B. Op. cit. P. 614.

${ }^{36}$ См.: Чешир Дж., Норт П. Указ. соч. С. 78.
}

то лицо, заявляющее требование вызвать противоположную сторону в английский суд, должно предварительно получить разрешение последнего. Опираясь на предписание закона, то есть в случаях, перечисленных в Правилах гражданского судопроизводства Англии 1998 г., часть 6 «Вручение документов», Практическое руководство 6Б «Вручение документов за пределами юрисдикции» (Civil Procedure Rules 1998, Part 6 «Service of documents», Practice Direction $6 \mathrm{~B}$ «Service out of the jurisdiction») $)^{37}$, английский суд может дать такое разрешение (the leave) в судебном заседании в отсутствие противоположной стороны (service of the writ out of the jurisdiction, assumed jurisdiction over an absent defendant, ex juris), если только заявитель сможет убедить суд в том, что Англия является надлежащим местом рассмотрения спора (forum conveniens, natural place of trial). «Суду предоставляется лишь новое право, которое он может использовать в конкретных случаях, относящихся, как он считает, по букве и духу к предусмотренным категориям дел» ${ }^{38}$.

В $§ 3.1$ Практического руководства 6Б закреплены основания, при наличии которых английский суд может по своему усмотрению принять решение о направлении судебной повестки за пределы своей юрисдикции ${ }^{39}$. Приведем лишь некоторые из них:

1) потенциальный ответчик (физическое или юридическое лицо) домицилирован в Англии 40 ;

2) истец просит суд вынести постановление, предписывающее ответчику совершить какоелибо действие либо воздержаться от совершения какого-либо действия в границах английской юрисдикции ${ }^{41}$ (например, судебное постановление, предписывающее ответчику не изымать его

\footnotetext{
${ }^{37}$ Cм.: <http://www.justice.gov.uk>. Новая редакция Правил гражданского судопроизводства Англии вступила в силу 30 апреля 2013 г.

38 Johnson v. Taylor Brothers [1920] A.C. 144, 153.

${ }^{39}$ Практическое руководство 6Б заменило действовавшее ранее Постановление 11, Правило 1 Правил судопроизводства в Верховном суде (Rules of the Supreme Court, Order 11, Rule 1).

${ }^{40}$ A claim is made for a remedy against a person domiciled within the jurisdiction (§ 3.1(1)).

${ }^{41}$ A claim is made for an injunction ordering the defendant to do or refrain from doing an act within the jurisdiction $(\S 3.1(2))$.
} 
имущество с территории Англии вплоть до рассмотрения предъявленного к нему иска - Mareva injunction ${ }^{42}$;

3) иск предъявлен в отношении договора (например, иск о признании договора недействительным), когда: договор заключен в пределах английской юрисдикции; договор заключен агентом, ведущим свои коммерческие дела или проживающим на территории Англии; договор регулируется английским правом; договор содержит положение о том, что суд компетентен рассматривать любой спор, связанный с данным договором ${ }^{43}$;

4) нарушение договора имело место в пределах английской юрисдикции ${ }^{44}$;

5) в иске утверждается о том, что договора не существует, однако если будет признано, что такой договор существует, он окажется соответствующим требованиям, изложенным в $3.1(6)^{45}$;

6) основанием иска является деликт, когда ущерб вследствие его совершения понесен в пределах юрисдикции английского суда, или понесенный ущерб явился результатом вредоносного действия, совершенного в пределах юрисдикции английского суда ${ }^{46}$;

7) иск предъявлен с целью приведения в исполнение судебного или арбитражного решения ${ }^{47}$;

8) предметом иска является собственность, расположенная в Англии ${ }^{48}$;

${ }^{42}$ См. об этом далее $\S 3$.

${ }^{43}$ A claim is made in respect of a contract where the contract (a) was made within the jurisdiction; (b) was made by or through an agent trading or residing within the jurisdiction; (c) is governed by English law; (d) contains a term to the effect that the court shall have jurisdiction to determine any claim in respect of the contract $(\S 3.1(6))$.

${ }^{44}$ A claim is made in respect of a breach of contract committed within the jurisdiction $(\S 3.1(7))$.

${ }^{45}$ A claim is made for a declaration that no contract exists where, if the contract was found to exist, it would comply with the conditions set out in paragraph $(6)(\S 3.1(8))$.

${ }^{46}$ A claim is made in tort where (a) damage was sustained within the jurisdiction; or (b) the damage sustained resulted from an act committed within the jurisdiction (§ 3.1(9)).

${ }^{47}$ A claim is made to enforce any judgment or arbitral award (§ 3.1(10)).

${ }^{48}$ The whole subject matter of a claim relates to property located within the jurisdiction $(\S 3.1(11))$.
9) предметом иска является исполнение условий письменного документа об учреждении траста, когда такое исполнение имеет место в соответствии с английском правом, а лицо, которому надлежит вручить судебную повестку, является доверительным собственником этого имущества ${ }^{49}$;

10) основанием искового требования является определение средств по управлению имуществом лица, умершего домицилированным на территории Англии ${ }^{50}$;

11) предметом иска выступает действительность завещания ${ }^{51}$;

12) иск предъявляется к лицу, действовавшему как конструктивный доверительный собственник, ответственность которого вытекает из действий, совершенных в пределах английской юрисдикции ${ }^{52}$;

13) предметом иска служит требование о реституции, когда ответчик несет ответственность за действия, совершенные в пределах английской юрисдикции ${ }^{53}$.

Необходимо отметить, что возможны ситуации, в которых различные нормы части 6 Правил гражданского судопроизводства Англии могут применяться одновременно. Для таких случаев английская судебная практика еще в бытность применения Постановления 11 Правил судопроизводства Верховного суда выработала следующий принцип: «нормы, содержащиеся в Постановлении 11, подлежат раздельному толкованию, причем каждый пункт сам по себе обладает полнотой и независим от других» ${ }^{54}$.

\footnotetext{
${ }^{49}$ A claim is made for any remedy which might be obtained in proceedings to execute the trusts of a written instrument where (a) the trusts ought to be executed according to English law; and (b) the person on whom the claim form is to be served is a trustee of the trusts $(\S 3.1(12))$.

${ }^{50}$ A claim is made for any remedy which might be obtained in proceedings for the administration of the estate of a person who died domiciled within the jurisdiction $(\S 3.1(21))$.

${ }^{51}$ A probate claim or a claim for the rectification of a will (§ 3.1(14)).

${ }^{52}$ A claim is made for a remedy against the defendant as constructive trustee where the defendant's alleged liability arises out of acts committed within the jurisdiction $(\S 3.1(15))$.

${ }^{53}$ A claim is made for restitution where the defendant's alleged liability arises out of acts committed within the jurisdiction (§ 3.1(16)).

${ }^{54}$ См.: Чешир Дж., Норт П. Указ. соч. С. 107.
} 
При этом судебный приказ, выдаваемый от имени суверена, может быть направлен ответчику, находящемуся в пределах территории Соединенного Королевства, например, в Шотландии, Северной Ирландии либо на острове Мэн. Ответчику, проживающему за границей, то есть за пределами Великобритании, направляется не судебная повестка, а уведомление о судебной повестке, чтобы «не оскорбить чувства иностранных властей» ${ }^{55}$.

Каким образом происходит выдача таких разрешений? Представляя письменные доказательства, заявитель (истец), желающий получить соответствующее разрешение суда, должен доказать наличие у него достаточных оснований и привести в соответствии с Правилами гражданского судопроизводства Англии 1998 г., часть 6, следующие доводы:

1) основания, перечисленные в Правилах гражданского судопроизводства Англии 1998 г., часть 6 , для направления судебной повестки или уведомления о судебной повестке за пределы юрисдикции;

2) подтверждение того, что иск имеет все основания быть удовлетворенным;

3) обоснование того, что Англия является наиболее подходящим местом рассмотрения иска хотя бы потому, что в ней короче сроки судопроизводства, либо налицо более продолжительный срок исковой давности;

4) доказательства того, что соответствующее решение английского суда будет признано и, при необходимости, приведено в исполнение за границей;

5) существует вероятность, что по политическим или иным причинам истец не может рассчитывать на справедливое судебное разбирательство за границей;

6) готовность английского суда признать, что иностранный суд будет применять закон, противоречащий общим представлениям деловых людей ${ }^{56}$.

В научной литературе отмечается, что суд должен проявлять большую осторожность в предоставлении разрешений, а в случае сомнения воздержаться от расширения своей «обычной»

\footnotetext{
${ }^{55}$ См.: Morris J.H.C. The Conflict of Laws. London, 1971. P. 64.

${ }^{56}$ См.: Чешир Дже, Норт П. Указ. С. 93.
}

юрисдикции, поскольку, вторгаясь в исключительную компетенцию иностранного суда, английский суд может нарушить общепризнанное доктриной общего права правило международного права - принцип соблюдения международной вежливости (comity of nations) ${ }^{57}$. В одном из дел апелляционным судом было признано, что если в конкретных обстоятельствах возникают какие-либо сомнения о применении положений Постановления 11, Правила 1 , то их следует толковать в пользу ответчика; одновременно необходимо полное и добросовестное раскрытие всех фактов стороной, подающей ходатайство ${ }^{58}$.

В заключение скажем, что английские суды весьма неохотно дают разрешение на вручение судебной повестки за пределами Англии при наличии соглашения сторон о подчинении споров исключительно юрисдикции иностранного суда ${ }^{59}$. Однако, судя по имеющимся в Англии прецедентам, данное правило применяется не столь жестко и безоговорочно. Так, в деле Evans Marshall and Co., Ltd. v. Bertola S.A. ${ }^{60}$, выдавая разрешение на вручение ответчику судебной повестки за границей, суд первой инстанции и Апелляционный суд нашли, что данное дело имеет исключительный характер, поскольку в силу различных фактов производство по нему тесно связано с Англией: существо требования касается сбыта вина в Англии, основные свидетели - англичане, второй ответчик по делу - английская компания; одновременно с этим процедура в испанском суде крайне медлительна по сравнению с процессом в английском суде ${ }^{61}$. Правила, воплощающие концепцию «forum conveniens», создают условия для гибкого решения вопроса о месте судебного производства с учетом особенностей конкретного

\footnotetext{
${ }^{57}$ CM.: Dicey and Morris. The Conflict of Laws. London, 1973. P. 173.

${ }^{58}$ The Hagen [1908] 189, 201; Bloomfield v. Serenyi [1945] 2 All E.R. 646.

${ }^{59}$ Скорее всего, исключительный характер юрисдикции будет установлен английским судом после тщательного исследования всех обстоятельств дела, особенно формулировки соглашения о подсудности. См., например: Sabah Shipyard (Pakistan) Ltd. v. Islamic Republic of Pakistan and Another [2002] EWCA Civ.1643 (Lexis).

${ }^{60}$ Evans Marshall and Co. Ltd. v. Bertola S.A. [1973] 1 W.L.R. 349.

${ }^{61}$ См.: Чешир Дж., Норт П. Указ. С. 93.
} 
дела, но они не позволяют сторонам достаточно точно предвидеть, где будет рассматриваться спор, который возник или может возникнуть из их правоотношения.

Напомним, что в случае, когда ответчик присутствует на территории Англии и истец имеет право вызвать ответчика в суд, доктрина «forum non conveniens» предоставляет возможность суду, наделенному полномочиями на рассмотрение и разрешение спора по общему праву, отказаться от юрисдикции в связи с тем, что Англия представляет собой неудобное место для рассмотрения дела. Сначала ответчик должен убедить судью, что существует другой суд, более подходящий для рассмотрения данного дела; далее, что истец, вызвав ответчика в английский суд, злоупотребил своими процессуальными правами, то есть вел себя недобросовестно, сделал это с намерением досадить ответчику (vexation) ${ }^{62}$, поставить его в тяжелое положение (oppression) ${ }^{63}$.

Вместе с тем иностранный суд, который может осуществить правосудие между сторонами, должен быть более удобным во всех смыслах: с точки зрения доступа к органам юстиции, беспристрастности судей, доступности доказательств и наличия свидетелей, стоимости и быстроты судопроизводства ${ }^{64}$, неприменение к спорным отношениям права Англии ${ }^{65}$, соглашение о подсудности в пользу зарубежного суда ${ }^{66}$, существование неоправданно больших трудностей у ответчика в осуществлении и защите своих прав и интересов в местном суде ${ }^{67}$ и проч. После этого, если английский судья посчитал убедительными доводы, представленные ответчиком, бремя доказывания переходит на истца, который должен показать, что в другом суде рассмотреть дело невозможно, так как он (истец) тогда будет лишен существенных личных и юридических преимуществ. В том числе истцу необходимо доказать, что он не сможет получить справедливое

${ }^{62}$ St. Pierre v. South American Stores (Gath and Chaves) Ltd. [1936] 1 K.B. 382, 389.

${ }^{63}$ McHenry v. Lewis [1882] 22 Ch.D. 397 (C.A.).

${ }^{64}$ Spiliada Maritime Corp. v. Cansulex Ltd. [1987] A.C. 460.

${ }^{65}$ Re Kernot (An Infant) (1965) Ch.D. 217; Re T. (Infants) [1968]

3 W.L.R. 430 (C.A.).

${ }^{66}$ The Fehmarn [1957] 1 W.L.R. 815.

${ }^{67}$ Re Norton's Settlement [1908] 1 Ch.D. 471. решение в другом суде. При этом доказательства должны быть вескими, а не голословными и базирующимися только на «опасениях истца» ${ }^{68}$.

Одновременно с этим отмечается, что если английский суд обладает юрисдикцией и рассматривает дело в так называемом «обычном порядке», свои сомнения он толкует в пользу истца ${ }^{69}$. Немногочисленная судебная практика в итоге выработала формулу, которая, как представляется, дает ориентиры английскому суду в деле соблюдения баланса интересов ответчика и истца в справедливом процессе ${ }^{70}$ : суд Англии признает себя «неудобным судом», когда, с одной стороны, процесс не предоставляет серьезных преимуществ истцу и, с другой стороны, влечет значительные неудобства для ответчика ${ }^{71}$. Одним словом, суды должны руководствоваться правилом, согласно которому судопроизводство может быть прекращено, когда того требует справедливость ${ }^{72}$. «Суд должен, с одной стороны, ясно отдавать себе отчет, что прекращая тяжбу, он не причиняет несправедливости, а с другой - должен вмешиваться всякий раз, когда ответчик возражает против рассмотрения дела в данном суде на том основании, что для него умышленно, с намерением досадить создается тяжелое положение, которое не возникло бы, если бы иск был предъявлен в другом доступном и компетентном суде» ${ }^{73}$.

Согласно принципу добросовестного соблюдения договорных обязательств (pacta sunt servanda), существует prima facie позиция, что иск, предъявленный в английском суде в отступление сторон от соглашения о подчинении спора иностранной юрисдикции, подлежит отклоне-

\footnotetext{
68 Черной против Дерипаски. Часть 1: Как Англия стала более подходящей, чем Россия. <http://zakon.ru/Blogs/ OneBlog/3787>.

${ }^{69}$ См.: Schneider B. Op. cit. P. 621.

${ }^{70}$ Logan v. Bank of Scotland [1906] 1 K.B. 141 (C.A. 1905); Maharanee of Baroda v. Wildenstein [1972] 2 All E.R. 689 (C.A.); The Atlantic Star (House of Lords) [1973] 2 All E.R. 175; [1973] 2 W.L.R. 795; Abidin Daver [1984] 2 W.L.R.196 (H.L.).

${ }^{71}$ См.: Schneider B. Op. cit. P. 628; Guillemard S., Prujiner A., Sabourin $F$. Les difficultes de l'introduction du forum non conveniens en droit quebecois // Les Cahiers de droit. 1995. Vol. 36. № 4. P. 919.

${ }^{72}$ McShannon v. Rockware Glass Ltd. [1978] A.C. 795.

${ }^{73}$ Logan v. Bank of Scotland [1906] 1 K.B. 141, 150.
} 
нию. У английского суда есть право усмотрения, согласно которому стороны подлежат юрисдикции английского суда в обычном режиме, когда ответчик присутствует на территории Англии. Суд не станет прекращать дело, если сочтет, что целям правосудия будет в большей мере отвечать рассмотрение дела в Англии ${ }^{74}$. Судья Брэндон в деле Eleftheria ${ }^{75}$ изложил принципы, вытекающие из руководящих прецедентов, на которых должно основываться решение о том, прекращать или не прекращать производство, когда истец возбуждает дело в Англии в нарушение действительного соглашения о подсудности иностранному суду, если спор в определенном отношении подпадает под юрисдикцию английского суда:

1) английский суд не обязан прекращать дело, а может решить вопрос об отказе в его рассмотрении по своему разумению;

2) суд прекращает судопроизводство в порядке осуществления этого дискреционного права, если не представлено веских доводов в пользу того, чтобы этого не делать;

3) бремя доказывания наличия таких веских оснований лежит на истце;

4) действуя по своему усмотрению, суд принимает во внимание все обстоятельства конкретного случая, в частности: а) в какой стране находятся или могут быть более легко получены доказательства по вопросам факта и какое влияние это может оказать на сравнительные удобства и стоимость рассмотрения дела в английском и иностранном судах; б) подлежит ли применению право зарубежного суда, и если подлежит, то отличается ли это право существенным образом от английского права; в) с какой страной и сколь тесно связана каждая из сторон; г) действительно ли ответчик стремится к рассмотрению дела в иностранном суде или только тактически желает получить преимущества; д) пострадает ли истец в связи с необходимостью предъявления иска в зарубежном суде из-за того, что не сможет получить исполнение вынесенного решения или столкнется с такой исковой давностью, которой нет в Англии, либо не сможет рассчитывать на

\footnotetext{
${ }^{74}$ The Fehmarn [1958] 1 All E.R. 333; The Adolf Warski [1976] 2 Lloyd's Rep. 241.

75 The Eleftheria [1970] 94, 100; [1969] 2 W.L.R. 1073.
}

справедливое разбирательство по политическим, расовым, религиозным или иным причинам ${ }^{76}$.

Доктрина «forum non conveniens» используется английскими судами и в случае заявления ответчиком о наличии параллельного разбирательства в суде иностранного государства: принцип lis alibi pendens является одним из аспектов доктрины «forum non conveniens» $»^{77}$. Если одно и тоже лицо предъявляет два иска из одного основания в двух различных английских судах, его поведение во всех случаях считается недобросовестным, и ответчик может потребовать, чтобы он ограничился каким-либо одним из двух процессов. Однако, если одно из дел возбуждено за границей, то такой выбор для истца совершенно не обязателен. Английский суд, несомненно, компетентен прекратить одно из дел, но это его дискреционное право, которое не столь легко осуществляется в пользу прекращения производства. «По ходатайству ответчика после некоторых колебаний суд может прекратить производство в английском суде, выдать судебный приказ о прекращении процесса в иностранном суде (anti-suit injunction) или потребовать от истца, чтобы тот выбрал одно из двух начатых судопроизводств» ${ }^{78}$.

В случае, когда истец в Англии является ответчиком за границей или ответчик в Англии является истцом в иностранном государстве, суды еще менее склонны вмешиваться, чем тогда, когда одно и тоже лицо является истцом в обеих странах, поскольку прекращение дела в таком случае ведет к тому, что сторона, против которой было заявлено ходатайство о прекращении, может быть поставлена в условия, менее благоприятные для защиты против иска. «Ведь представляется ясным, что одна лишь множественность производств не должна рассматриваться как обстоятельство, неудобное для ответчика» ${ }^{79}$.

Заметим, что в странах континентального права (civil law countries), в отличие от стран общего права (common law countries), если суд компетентен по праву своей страны, то его не интересует, имеют ли юрисдикцию еще какие-

\footnotetext{
${ }^{76}$ Цит. по: Vanderlinden J. Les conflits de lois. Bruxelles, 2004. Vol. 22. P. 65-68.

${ }^{77}$ См.: Schneider B. Op. cit. P. 620.

78 Чешир Дюс., Норт П. Указ. С. 136.

${ }^{79}$ Там же. С. 137.
} 
либо другие суды. Он должен принять дело к рассмотрению. Судьи в континентальных правопорядках руководствуются представлением, что если правила, определяющие международную судебную юрисдикцию, соблюдены, то права ответчика a priori не могут быть ущемлены, поскольку предписания процессуального права направлены на учет интересов ответчика ${ }^{80}$. В европейских правопорядках существует тенденция перенесения норм, регулирующих внутреннюю (территориальную) подсудность, на международную почву. В немецком праве правила, определяющие международную судебную юрисдикцию, находятся в общих законах по вопросам судоустройства и судопроизводства среди предписаний, определяющих территориальную подсудность (§ 12 и сл. Гражданского процессуального уложения (ГПУ) Германии). Такого рода трактовка территориальной подсудности в немецкой доктрине именуется теорией двойной функции (Doppelfunktionstheorie).

Компетенция французского суда по национальным и международным делам определяется в соответствии с одними и теми же правилами Гражданского процессуального кодекса Франции ${ }^{81}$. Правда, во французской правовой системе имеются специальные положения, легитимирующие расширенную международную юрисдикцию французских судов и критикуемые в европейской доктрине за «чрезмерную» подсудность. Согласно предписаниям ст. 14 и 15 Французского гражданского кодекса (далее - ФГК) для подчинения иска юрисдикции французского суда, по общему правилу, достаточным является наличие французского гражданина в качестве стороны спорного правоотношения. Ст. 14 ФГК гласит: «Иностранец, даже не находящийся во Франции, может быть вызван во французские суды для выполнения обязательств по договору, заключенному во Франции и с французом; он может быть привлечен во французские суды в связи с обязательствами по договору, заключенному

\footnotetext{
${ }^{80}$ См.: Gaudemet-Tallon H. Les regimes relatif au refus d'exercer la competence juridictionnelle en matiere civile et commerciale: forum non conveniens, lis pendens // Revue internationale de droit compare. Avril-juin 1994. Vol. 46. № 2. P. 427.

${ }^{81}$ Code de procédure civile, Titre III: La compétence. $<$ http://www. legifrance.gouv.fr>.
}

им в иностранном государстве с французом». Ст. 15 ФГК устанавливает правило: «Француз может быть привлечен к суду во Франции в связи с обязательствами по договору, заключенному им в иностранном государстве, даже если его контрагентом является иностранец» ${ }^{82}$.

Выражение «forum non conveniens» не известно французской правовой системе. Однако французскому праву известны другие процессуальные механизмы, используя которые французский суд может отказаться от осуществления правосудия в пользу иностранного суда: возражение о наличии параллельного производства (l'exception de litispendance) и о рассмотрении связанного, родственного дела за границей (l'exception de connexite) $^{83}$. Долгое время суды Франции не отказывались от своей компетенции в случаях, когда иностранный суд первым принял дело к производству и начал рассмотрение иска между одними и теми же сторонами по одному и тому же основанию.

Вдохновленный французской доктриной, в частности, работой известного французского ученого Д. Холло (Holleaux D. La litispendance internationale», T.C.F.D.I.P., 1971-1973), Кассационный суд Франции пересмотрел свою предыдущую практику, и в деле Miniera di Fragne (Civ. 1re, 26 nov. 1974, R.C. 1975) признал возможность заявления перед французским правосудием возражения о наличии параллельного производства в иностранном суде. Теперь, если французский суд сталкивается со случаями заявления о наличии параллельного иностранного производства по делу между одними и теми же лицами по одному и тому же основанию, когда и французский, и иностранный суды обладают международной юрисдикцией, французский судья может принять такое возражение и отказаться от рассмотрения спора, но только в случае, если будущее решение иностранного суда по соответствую-

\footnotetext{
${ }^{82}$ См.: <http://www.legifrance.gouv.fr>.

83 Термин "forum conveniens" встречается во французской науке МЧП, если речь идет о случаях признания французским судом своей международной компетенции, когда, согласно французскому позитивному праву, последняя отсутствует. Доктриной "forum conveniens" охватываются случаи принятия дела к рассмотрению в ситуации возможного отказа в правосудии.
} 
щему разбирательству может быть признано и исполнено на французской территории ${ }^{84}$. Как видно, в случае заявления о параллельных разбирательствах в судах различных государств французский судья, так же как его английский коллега, может по своему разумению и с учетом конкретных обстоятельств отказаться от своих полномочий в пользу иностранного суда, но мотивы и основания, которыми руководствуются судьи обоих государств, будут совершенно различными.

Немного отступая от основной темы, скажем, что позиция французского права в вопросе признания и исполнения иностранных судебных решений практически полностью выступает как результат длительной эволюции судебной практики. На сегодняшний день ключевыми для позиции французского правосудия в этом вопросе стали следующие постановления Кассационного суда: Munzer, Cass.civ.1, 7 janvier 1964; Bachir, Cass.civ.1, 4 octobre 1967; Simitch, Cass.civ.1, 6 fevrier 1985; Pordea, Cass.civ.1, 16 mars 1999; Cornelissen, Cass. civ.1, 20 fevrier 2007.

В итоге сегодня условия экзекватуры определяются по формуле, данной в решении Кассационного суда по делу Cornelissen. Сводится она, по сути, к следующему: для того чтобы выдать экзекватуру в случае, когда отсутствует международное соглашение, французский суд должен убедиться, что выполнены три условия, а именно: наличие международной компетенции у иностранного суда; соответствие постановления иностранной судебной инстанции международному публичному порядку применительно к существу спора и к процедуре; отсутствие обхода закона. Третье условие об обходе закона на практике почти всегда поглощается одним из первых двух ${ }^{85}$. И никаких рассуждений о взаимности со стороны иностранного государства!

Что касается признания за иностранным судом международной юрисдикции по рассмотрению спора, то французское правосудие решает этот вопрос в каждом конкретном случае отдельно, опираясь не на объективные правила

\footnotetext{
${ }^{84}$ См.: Gaudemet-Tallon H. Op. cit. P. 429.

${ }^{85}$ См. об этом более подробно: Литвинский Д. Газпромбанк во Франции: все в полной экзекватуре. <http://zakon.ru/Blogs/ gazprombank_vo_francii_vse_v_polnom_ekzekvature/5674>.
}

установления международной подсудности, собственные либо соответствующего иностранного государства, а исходя из существования действительной связи между спором и разрешившим его иностранным судом. Такая связь может следовать из факта наличия одинакового места жительства либо гражданства у участников зарубежного процесса, а также отсутствия исключительной компетенции у французского суда.

Ст. 23 Регламента Брюссель I ${ }^{86}$ предоставляет возможность сторонам договора для случаев возникновения спора заранее избрать компетентный суд. Данный суд имеет исключительное право рассматривать такой спор. С целью предупреждения параллельного производства по одному и тому же делу в судах государств членов Европейского Союза в ст. 27 Регламента Брюссель I закреплен специальный механизм функционирования принципа lis alibi pendens, который предусматривает следующее: 1. Если были предъявлены иски к одним и тем же сторонам, по одному и тому же основанию в суды различных государств, то суд, который вторым принял дело к производству, приостанавливает разбирательство по нему до тех пор, пока не будет установлена юрисдикция суда, который первым принял иск к рассмотрению. 2. Как только установлена юрисдикция суда, первым принявшего дело к производству, любой другой суд отказывается от своей юрисдикции в пользу первого суда. Толкование смысла этих норм, данное Судом ЕС, определило европейский режим принципа lis alibi pendens, а также соотношение данного института с соглашением о подсудности (пророгационным соглашением), определенным тем же Регламентом в ст. 23.

В деле Eric Gasser GmbH (австрийская компания) v. MISAT Srl (итальянская компания), отвечая на преюдициальный запрос австрийского суда (Oberlandesgericht Innsbruck), Суд ЕС пришел

\footnotetext{
${ }^{86}$ Регламент Брюссель I содержит правила, определяющие международную судебную юрисдикцию по гражданским и торговым делам, а также признание и приведение в исполнение иностранных судебных решений на территории Европейского Союза. 6 декабря 2012 г. Совет ЕС, объединяющий министров юстиции стран-участниц, утвердил изменения в данный регламент. Новый порядок начинает действовать с 2015 года, а новая редакция данного регламента будет именоваться Регламент Брюссель I bis.
} 
к выводу, что наличие действительного соглашения о подсудности, как оно предусмотрено в ст. 23 Регламента Брюссель I, не затрагивает действие ст. 27 того же акта. Это означает, что суд, имеющий исключительную компетенцию для рассмотрения и разрешения спора в силу соглашения о подсудности, не обладает преимуществом перед другим судом в случае существования параллельного производства по идентичному делу в судах различных государств. В этом же постановлении Суд ЕС в ответ на заявление о том, что сроки рассмотрения дела в итальянском суде превышают все разумные пределы и тем самым нарушают право каждого на справедливое судебное разбирательство в соответствии со ст. 6 Европейской конвенции о защите прав человека и основных свобод от 4 ноября 1950 г., определил, что в силу наличия в ЕС принципа взаимного доверия в осуществлении правосудия итальянский суд, первый принявший дело к производству, даже при наличии соглашения сторон о рассмотрении споров в австрийском суде, будет обладать приоритетом. По мнению Суда ЕС, «положение второго судьи не лучше положения первого судьи в вопросах определения своей юрисдикции» ${ }^{87}$.

Новая редакция Регламента Брюссель I bis содержит унифицированные нормы, применяющихся к ситуациям, когда один и тот же спор находится в производстве сразу нескольких судов. Если раньше общие правила определяли порядок решения этой проблемы только в том случае, когда соответствующие суды были судами государств - членов ЕС, то теперь общим регулированием на уровне ЕС охвачены и такие ситуации, когда «конкурирующая» юрисдикция находится за пределами ЕС.

\section{§ 3. Особые судебные приказы и штрафы в английском, американском и французском праве}

Судебный приказ о запрете иностранного cyдопроизводства. Английское правосудие имеет в своем арсенале инструмент, называемый «anti-suit injunction» (судебный приказ о запрете

${ }^{87}$ CJCE, 9 décembre 2003, Gasser c. MISAT (дело C-116/02), п. 48,73 . иностранного судопроизводства). Регулирование этого института содержится в статутном праве Англии, а именно в ст. 37 Закона «О старших судах» 1981 г. (Senior Courts Act 1981) ${ }^{88}$. Речь идет о дискреционном праве английских судов выносить решение (предварительное или окончательное), предписывающее стороне, участвующей в английском судопроизводстве, не начинать либо прекратить производство в суде другого государства ${ }^{89}$. Как видно из определения закона, английский суд вмешивается не только в случае наличия параллельного разбирательства по одному и тому же либо родственному делу в английском и иностранном судах ${ }^{90}$. Данная процессуальная мера может применяться в английском судопроизводстве и при других обстоятельствах, когда налицо конфликт юрисдикций двух различных государств.

В английской доктрине отмечается, что судебный приказ anti-suit injunction выполняет ту же самую функцию, что и доктрина «forum non conveniens». В основе этих конструкций лежит общий принцип: для рассмотрения каждого конкретного дела есть только свой подходящий суд. Вместе с тем наличие общих целей у двух институтов английского права не позволяет ставить знак равенства между ними. В одном случае английский суд рассматривает возможность ограничения своей юрисдикции, а в другом определяет, хотя и косвенно, компетенцию иностранного суда. На этот факт обратил внимание Лорд Гофф в деле Airbus Industrie GIE v. Patel and others, рассмотренном Палатой Лордов в 1998 г. ${ }^{91}$ : «оба средства (и приостановка судопроизводства, и судебный приказ) имеют своей целью опре-

\footnotetext{
${ }^{88}$ Cм.: <http://www.legislation.gov.uk/ukpga/1981/54>.

89 Заметим, что в деле Airbus Industrie GIE v. Patel, pacсмотренном Палатой Лордов в 1998 г., английский суд, не будучи задействованным в данных обстоятельствах, рассматривал возможность вынесения судебного предписания для разрешения конфликта юрисдикций между штатом Техас и Индией.

${ }^{90}$ Сразу оговоримся, что в соответствии с английскими, американскими и европейскими доктринальными источниками, которые нам удалось изучить по данному вопросу, в действительности существует лишь очень немного дел, по которым суд вынес постановление о прекращении производства по делу.

${ }^{91}$ Airbus Industrie GIE v. Patel and Others [1998] UKHL 12; [1999] 1 AC 119; [1998] 2 All ER 257; [1998] 2 W.L.R 686.
} 
деление надлежащего суда для рассмотрения спора. В случае приостановки судопроизводства национальный суд уясняет для себя, должен ли он при данных обстоятельствах установить свою юрисдикцию, в то время как в случае применения приказа он в действительности определяет предмет юрисдикции для иностранного суда» ${ }^{92}$.

Сформированный правом справедливости в суде Лорда-канцлера, институт судебного приказа anti-suit injunction нацелен на восстановление законности в случаях, когда истец, вызвав противоположную сторону в иностранный суд, злоупотребил своим правом на предъявление иска (abuse of the process of the court) ${ }^{93}$. В настоящее время при вынесения постановления, предписывающего стороне не начинать либо прекратить производство в суде другого государства, английский судья будет опираться на особые правила, сформулированные английским прецедентным правом за последние сто лет. Рассмотрим основные мотивы, которыми будут руководствоваться судьи при принятии решения о выдаче судебного приказа anti-suit injunction.

В самом начале судопроизводства в Англии ответчик в иностранном судопроизводстве должен убедить английский суд в том, что в данном конкретном деле именно Англия является надлежащим местом рассмотрения спора (natural place of trial). При этом, как было отмечено в деле Castanho v. Brown\&Root Co. (UK) Ltd. ${ }^{94}$, английское правосудие должно ориентироваться на подходы, сформулированные английским правом для доктрины forum non convenies. B данном случае английский суд должен быть более удобным, чем иностранный суд, как это было установлено в деле Spiliada Maritime Corp. v. Cansulex Ltd. (1987), с точки зрения доступа к органам юстиции, беспристрастности судей,

92 "Both the remedy of a stay and an injunction have as their main objectives the selection of an appropriate forum for the trial of an action. In case of the stay, the domestic court determines for itself whether in the circumstances it should take jurisdiction whereas, in the case of the injunction, it in effect determines the matter for the foreign court".

${ }^{93}$ В ходе деятельности канцлерского суда сложились особые нормы, основанные на прецедентах, совокупность которых и образовала право справедливости, чьим девизом служит выражение: "Equity will not suffer a wrong to be without a remedy".

${ }^{94}$ Castanho v. Brown \& Root Co. (UK) Ltd. [1981] A.C. 557, 575. доступности доказательств и наличия свидетелей, стоимости и быстроты судопроизводства. После этого, если английский судья посчитал убедительными доводы, представленные ответчиком, бремя доказывания переходит на истца в иностранном судопроизводстве, который должен показать, что в суде Англии рассмотреть дело невозможно, так как он в этом случае будет лишен существенных личных и юридических преимуществ, которые ему предоставляет зарубежная судебная процедура. В подтверждение вышесказанного приведем слова Лорда Скармана, которые он произнес, вынося решение по делу Castanho v. Brown \& Root Co. (UK) Ltd.: «для вынесения приказа ответчик должен показать, что (а) английский суд является именно тем судом, в котором судопроизводство может быть осуществлено значительно удобнее и дешевле; (б) приказ не должен лишить истца тех личных и правовых преимуществ, которые доступны ему в иностранном суде ${ }^{95}$. Следует подчеркнуть, что именно на лицо, желающее получить приказ о прекращении зарубежного судопроизводства, ложится основное бремя доказывания соответствующих фактов в английском суде ${ }^{96}$.

Во вторую очередь ответчик в иностранном процессе должен представить английскому суду доказательства того, что истец в зарубежном судопроизводстве (он же ответчик в английском разбирательстве) злоупотребил своим правом и из тактических соображений начал процесс в иностранном суде. Вот какие аргументы привел Лорд Скратон в обоснование своего решения о вынесении судебного приказа anti-suit injunction в деле Cohen v. Rothfield (1919) ${ }^{97}$ : для прекращения дела необходимо, чтобы процесс в иностранном суде не просто ставил в тяжелое положение сторону, ходатайствующую о таком прекращении, но был бы рассчитан на то, чтобы причинить ей серьезный, если не непоправимый ущерб; кроме

\footnotetext{
95 "....to justify an injunction the defendants must show: (a) that the English court is a forum to whose jurisdiction they are amenable in which justice can be done at substantially less inconvenience and expense and (b) the injunction must not deprive the plaintiff of a legitimate personal or juridical advantage which would be available to him if he invoked the (foreign) jurisdiction".

${ }^{96}$ Meall und Rohstoff AG v. A.C.L.I. Metals (London) Ltd. [1984] 1 Lloyd's Rep. 598, 613 (C.A.).

${ }^{97}$ Cohen v. Rothfield [1919] 1 K.B. 410, 415.
} 
того, иностранная судебная процедура должна быть совершенно бесполезной и неоправданной.

Так, в деле Airbus Industrie GIE v. Patel and others, рассматривая возможность вынесения судебного приказа о прекращении производства в техасском суде, английский суд указал, что обстоятельства дела в совокупности свидетельствуют о том, что предъявив иск не в суде Индии, на территории которой собственно и произошло крушение самолета Airbus, а в суде штата Техас, истцы злоупотребили своим правом на предъявление иска. Обстоятельства, нарушающие баланс интересов истца и ответчика в данном деле, были следующими: «чрезмерная» компетенция техасского суда; нежелание суда штата удовлетворить ходатайство об использовании доктрины forum non conveniens; применение совсем не связанного с обстоятельствами дела права страны суда; объективная, то есть безвиновная ответственность деликвента, предусмотренная законодательством штата Техас.

Еще одним основанием для применения судебного приказа anti-suit injunction, кстати, наиболее часто встречающимся в практике английских судов, является обращение стороны договора в иностранный суд в нарушение соглашения о подчинении спора юрисдикции английского суда либо договоренности о передаче спора для разрешения в арбитраж на территории Англии ${ }^{98}$. В данном случае, по мнению английского правосудия, нарушается основной принцип общего права о добросовестном исполнении договорных обязательств. Напоследок заметим, что неповиновение английскому суду грозит наказанием соответствующей стороны за неуважение к суду (contempt of court). В законе «О неуважении к суду» (Contempt of Court Act) 1981 г.99 перечислены санкции, применяемые в случае оскорбления суда: лишение свободы, арест имущества (writ of sequestration), присуждение штрафа либо невозможность для ответчика аргументировать

\footnotetext{
${ }^{98}$ Определяющими позицию английской судебной доктрины в данном вопросе являются следующие решения по делам: Continental Bank NA vUelos Naviera SA [1994] 2 All ER, Lloyd's Rep. 505 (C.A.); Aggeliki Charis Compania Maritima SA v Pagnan SpA, The. Angelic Grace [1995] 1 Lloyd's Rep 87; Donohue v. Armco Inc [2001] UKHL 64; [2002] 1 Lloyd's Rep 425.

${ }^{99}$ Cм.: <http://www.legislation.gov.uk/ukpga/1981/49>.
}

свою позицию и участвовать в английском судопроизводстве.

Вопрос о соответствии английской практики вынесения подобных приказов европейским правилам о международной судебной юрисдикции было рассмотрено в преюдициальном порядке Судом ЕС по делу Gregory Paul Turner v. Felix Fareed Grovit, Harada Ltd. и Changepoint SA. (C-159/02, решение от 27 апреля 2004 г. $)^{100}$. Фабула дела такова. Господин Тернер, домицилированный в Англии, будучи служащим испанского предприятия Harada Ltd., и работающий в Мадриде на англо-испанскую группу компаний Chequepoint Group, в 1998 г. предъявил иск к своему работодателю в английский трибунал по рассмотрению трудовых споров (Employment Tribunal) с требованием о возмещении убытков за вынужденное прекращение трудовых отношений. По словам господина Тернера, его заставляли совершать незаконные действия, принуждая тем самым к увольнению. Трибунал по рассмотрению трудовых споров и затем Апелляционный суд Англии и Уэлльса удовлетворили требования истца.

В то же самое время компания Changepoint SA заявила о своих претензиях к господину Тернеру, предъявив иск о возмещении убытков (в размере 85 млн испанских лир), причиненных ненадлежащим исполнением последним своих трудовых обязанностей, в суд первой инстанции в Мадриде. 28 мая 1999 г. господин Тернер обратился в Апелляционный суд Англии и Уэлльса с просьбой выдать приказ в отношении господина Гровита, компаний Harada Ltd. и Changepoint SA о прекращении судопроизводства в Испании, а также о воздержании от инициирования будущих судебных процессов, касающихся трудовых отношений с господином Тернером, как в Испании, так и в любом другом государстве.

Удовлетворив просьбу господина Тернера о выдаче предписания, английский суд обосновал свое решение следующим образом: 1) истец участвовал в английском судопроизводстве; 2) ответчики предъявили иск в испанском суде единственно с целью воспрепятствовать осуществляемой в Англии судебной процедуре; 3 ) предъявленные господином Тернером доказательства подтверждают

\footnotetext{
${ }^{100}$ См.: $<$ http://eur-lex.europa.eu/LexUriServ/LexUriServ.do?ur $\mathrm{i}=$ CELEX:62002CJ0159:EN:NOT>
} 
необходимость предоставить ему необходимую защиту в английском суде. 28 июня 1999 г. компания Changepoint SA отказалась от своего иска в суде Испании. Чтобы оспорить постановление английского апелляционного суда, господин Гровит, компании Harada Ltd. и Changepoint SA обратились в Палату Лордов. В своей апелляции они, в частности, отметили, что английские суды не вправе выносить решения, препятствующие производству в судах государств - участников Брюссельской конвенции 1968 г. о юрисдикции, признании и исполнении судебных решений по гражданским и торговым делам ${ }^{101}$ (далее - Брюссельская конвенция).

Вынося свое решение о несоответствии практики английских судов европейским нормам, Суд ЕС постановил следующее: 1) в силу того, что в основу Брюссельской конвенции положен принцип взаимного доверия к правовым системам и органам юстиции государств, участвующих в этом международном соглашении, суды государств-участников обладают одинаковыми полномочиями и авторитетом в толковании и применении правил, закрепленных в ней; 2) обращенное к определенному лицу предписание английского суда, запрещающее начинать либо повелевающее прекратить судопроизводство в иностранном суде под угрозой применения к такому лицу санкций за неисполнение приказа, несмотря на свой характер in personam (личный характер), посягает на компетенцию зарубежного суда рассматривать и разрешать дело по существу, что является недопустимым вмешательством в юрисдикцию судов другого государства и противоречит системе норм Брюссельской конвенции.

В заключение скажем, что странам, принадлежащим к романо-германской правовой системе, не известен институт судебного приказа anti-suit injunction. Во Франции, например, компетенция иностранного суда выносить решения проверяется, как мы уже выяснили, на стадии признания и исполнения решений на французской территории. В то же время весьма любопытным представляется недавнее постановление Кассационного

\footnotetext{
${ }^{101}$ На момент рассмотрения споров в английском и испанском судах общим для них источником европейского процессуального права именно Брюссельская конвенция.
}

суда Франции, разъясняющее, как нам кажется, позицию французского правосудия относительно возможности получения экзекватуры на судебный приказ anti-suit injunction, выданный судом страны, принадлежащей англо-саксонской системе права ${ }^{102}$. Обстоятельства дела были таковы. Французская компания обратилась в Кассационный суд Франции с жалобой на решение Апелляционного суда города Версаля, выдавшего экзекватуру на постановление американского суда штата Джорджия, которое предписывало французской компании прекратить судебное разбирательство во французском суде.

Обосновывая свою позицию, французская компания заявила, что выдача американским судом приказа, запрещающего начинать либо повелевающего прекратить судопроизводство во французском суде, без того чтобы французский суд сам рассмотрел вопрос о своей компетенции, нарушает право на справедливое судебное разбирательство, закрепленное ст. 6 Европейской конвенции о защите прав человека и основных свобод $1950 \Gamma^{103}$. Во французской доктрине международного частного права признается, что вышеуказанная статья определяет содержание международного публичного порядка применительно к судебной процедуре. Кассационный суд Франции отверг доводы французской компании и объяснил свою позицию следующим образом: в силу того обстоятельства, что компетенция американского суда основывалась на добровольном соглашении сторон о передаче дела в суд штата Джорджия, предписание американского суда о соблюдении данного соглашения, если только иное не предусмотрено международными обязательствами Франции либо правом ЕC, не может нарушать французский международный публичный порядок.

Судебный приказ о наложении ареста на активы ответчика. В Великобритании вопрос о применении обеспечительных мер в национальном и международном гражданском судо-

\footnotetext{
${ }^{102}$ Arrêt n ${ }^{\circ} 1017$ du 14 octobre 2009 (08-16.369/08-16.549) / Cour de cassation - Première chambre civile.

${ }^{103}$ Европейский суд по правам человека (ЕСПЧ) в деле Golder v. Great Britain от 21 февраля 1975 г. решил, что право на справедливое судебное разбирательство должно пониматься как право на доступ к правосудию, причем этот доступ должен быть не теоретическим, а реальным и эффективным.
} 
производстве решается на основании общего и статутного права. К числу таких мер относятся запрет Марева (Mareva injunction), представляющий собой не что иное, как арест имущества или денежных средств, принадлежащих ответчику, а также запрет покидать территорию юрисдикции английского суда (ne exeat regno), представляющий собой принудительное задержание ответчика. В качестве основания для применения запрета Марева выступает Закон «О Верховном Суде» 1981 г. В соответствии с п. 3 ст. 37 закона Высокий Суд наделяется дискреционным полномочием издавать приказы, содержащие запрет Марева, в отношении активов, находящихся в пределах его юрисдикции, независимо от домицилия или присутствия ответчика на территории Англии. Анализируя текст п. 3 ст. 37, можно выделить три элемента, необходиых для принятия приказа о запрете Марева:

1) активы ответчика должны находиться на территории Англии, т.е. под юрисдикцией английского суда;

2) приказ суда может быть выдан только в отношении ответчика как стороны в споре, а не в отношении третьих лиц;

3) приказ суда может быть выдан только в случае правомерного установления юрисдикции по существу спора независимо от домицилия или местонахождения ответчика.

Каковы же существенные характеристики запрета Марева по английскому праву?

1) запрет Марева не выступает как самостоятельное основание иска, а носит исключительно вспомогательный характер, в силу этого невозможно установить юрисдикцию суда, только лишь используя формальные признаки для его принятия;

2) запрет Марева не является средством обеспечения исполнения обязательств и тем самым не придает истцу статуса привилегированного кредитора в случае банкротства ответчика;

3) запрет Марева, выданный до принятия судебного решения, продолжает свое действие и после вступления судебного решения в силу вплоть до его полного и окончательного исполнения.

Если принятие запрета Марева в отношении активов ответчика - иностранного физического или юридического лица, находящихся на территории Англии, не вызывает каких-либо вопросов, то наибольшие споры вызывает принятие запрета Марева в отношении активов, находящихся на территории иностранных государств. Обладает ли английский суд компетенцией издавать приказы о запрете Марева, носящие экстратерриториальный характер, в отношении ответчикаиностранца? Апелляционный Суд Англии дал положительный ответ на поставленный вопрос в деле Derby\&Co Ltd. v. Weldon (1989)104. При этом, по мнению суда, должны быть соблюдены следующие требования:

1) принятие запрета Марева, носящего экстратерриториальный характер, должно осуществляться в исключительных случаях с учетом всех обстоятельств конкретного дела;

2) принятие запрета Марева, носящего эктратерриториальный характер, должно основываться в целом на тех ключевых элементах, которые характерны и для обычного запрета Марева;

3) эктратерриториальный запрет Марева не должен вступать в противоречие с общими принципами международного права.

Последнее положение нуждается в более детальном пояснении. Различные акты, принимаемые судом какого-либо государства, имеют законную силу и действуют только в пределах его территории в силу общепризнанных принципов международного права, а именно, территориальной целостности и суверенного равенства государств. Исходя из этих принципов, становится очевидным, что публичные акты властных органов одного государства не распространяются на территорию других государств. Но экстратерриториальный запрет Марева как раз и имеет целью распространить свое действие на территорию тех государств, где имеются активы ответчика-иностранца. Каким же образом английское общее право разрешает этот конфликт между экстратерриториальным характером запрета Марева и непротиворечием принципам международного права?

Общее право Великобритании предусматривает включение специальной оговорки Бабанафт (Babanaft proviso) в эктратерриториальный запрет Марева, позволяющей снять вышеупомянутое противоречие. Суть этой оговорки сводится к тому, что эктратерриториальный запрет Марева

${ }^{104}$ Derby \& Co Ltd. v. Weldon case [1989] 2 W.L.R. 276 (C.A.). 
имеет силу в пределах иностранного государства, только если он признан судом этого государства и тем самым может быть приведен в исполнение. Таким образом, по смыслу английского общего права запрет Марева как обычного, так и экстратерриториального характера непосредственно действует в отношении ответчика; что же касается третьих лиц, то их права и интересы за пределами Великобритании защищает оговорка Бабанафт. Под третьими лицами чаще всего имеются в виду банки, в которых находятся денежные счета ответчика. В отношении счетов, находящихся в британских банках или британских филиалах иностранных банков, запрет Марева действует автоматически, что означает обязанность немедленного замораживания всех счетов ответчика под угрозой в случае неповиновения быть оштрафованными за неуважение к суду и неповиновение судебным приказам. Счета ответчика в иностранных банках за пределами Великобритании могут быть заморожены на основании эктратерриториального запрета Марева только в случае его признания и приведения в исполнение судом иностранного государства в силу оговорки Бабанафт.

Запрет ответчику покидать территорию Великобритании как мера обеспечения иска в гражданском судопроизводстве вызывает ожесточенные споры в силу своего исключительно сурового характера. Истоки этого запрета лежат в Законе «О должниках» (Debtors Act) 1869 г. ${ }^{105}$, согласно которому ответчик может быть подвергнут аресту, если соблюдены следующие условия:

1) цена иска составляет не менее 50 фунтов стерлингов;

2) есть основания полагать, что ответчик собирается покинуть территорию Англии;

3) отсутствие ответчика может серьезно повилять на ход судебного разбирательства.

Неоднократно поднимался вопрос о том, что эти положения Закона «О должниках» существенным образом нарушают гражданские права и свободы личности, так как ответчик может быть арестован (запрет предусматривает сдачу паспорта властям и содержание под стражей) всего лишь в ходе гражданского судопроизводства, не будучи обвиняемым в совершении уголовного преступ-

${ }^{105}$ CM.: <http://www.legislation.gov.uk/ukpga/Vict/32-33/62>. ления. Кроме этого, суд может не удовлетворить исковые требования истца, и в таком случае применение вышеуказанного запрета будет совершенно неоправданным. Несмотря на жесткую критику запрета, английский суд в относительно недавнем решении по делу Al Nahkel Trading Ltd. v. Lowe (1986) ${ }^{106}$ подтвердил его действенность и применимость в гражданском процессе и в настоящее время.

В международном гражданском судопроизводстве на территории США также возможно применение мер обеспечения исковых требований истца. В целом позиция американских судов приближается к позиции английских судов по данному вопросу, однако нельзя не отметить тот факт, что есть и ряд отличий, правда, не имеющих принципиального характера. Позиция американского суда по вопросу принятия обеспечительной меры в форме замораживания активов ответчика (наложение ареста на его имущество) была сформулирована в решении Верховного Суда США по делу US v. First National City Bank (1965) 107 и заключается в следующем: если юрисдикция американского суда правомерно установлена в отношении ответчика, то федеральный окружной суд имеет право издать приказ о замораживании имущества (активов), находящихся под контролем ответчика, независимо от их расположения на территории США или за ее пределами. Анализируя подход американского суда к рассматриваемому вопросу, можно выделить несколько условий изданий судебного приказа о наложении ареста на имущество ответчика:

1) американский суд должен обладать юрисдикцией в отношении конкретного спора;

2) имущество должно находиться под контролем ответчика, а не формально принадлежать ему на праве собственности;

3) факт нахождения имущества на территории США или за ее пределами никакого значения не имеет.

В отличие от английского общего права общее право США не предусматривает включение в приказ о замораживании активов ответчика оговорки, аналогичной оговорке Бабанафт, по-

\footnotetext{
${ }^{106}$ Al Nahkel Trading Ltd. v. Lowe case [1986] 2 W.L.R. 317(Q.B.).

${ }^{107}$ US Supreme Court Reports (1965) 13 L ed 2d. P. 367-371.
} 
этому вопрос об экстратерриториальном действии данного приказа в отношении третьих лиц остается открытым.

Особый судебный штраф (астрэнт). Мерой, побуждающей должника к исполнению вынесенного в отношении него судебного решения (об уплате денежного долга, о совершении или воздержании от тех или иных действий, не связанных с уплатой денежного долга), может быть применение особого судебного штрафа, получившего в процессуально-правовой науке название «институт астрэнта» (фр. astreinte) ${ }^{108}$ - особого судебного штрафа. Перед тем как приступить к осуществлению процедуры принудительного исполнения судебного решения, кредитор может стимулировать должника добровольно исполнить такое решение. В начале XIX века для этой цели, а также для восполнения имевшихся в то время пробелов в системе правового регулирования принудительного исполнения судебных решений о присуждении к исполнению обязательства в натуре, французской судебной практикой был создан институт особого судебного штрафа с опорой на принцип, закрепленный в ст. 1142 ФГКФ. Ст. 1142 ФГК гласит, что неисполнение любого обязательства сделать или не делать что-либо предоставляет кредитору право требовать возмещения убытков вне зависимости от того, является ли такое неисполнение виновным. Механизм применения особого судебного штрафа был кодифицирован только в конце XX века Законом Франции от 5 июля 1972 г.

Суть института особого судебного штрафа состоит в том, что суд, вынося решение по иску о присуждении к совершению тех или иных действий либо о воздержании от совершения тех или иных действий, возлагает на должника обязанность уплачивать периодические пени за каждый день (неделю, месяц и т.п.) неисполнения судебного решения. Причем согласно французскому праву сумма этого штрафа поступает не в бюджет, а самому истцу. В ряде других стран сумма такого штрафа делится между бюджетом и истцом (например, Португалия). Именно поэтому есть все основания обозначить данный процессуальный институт как особый судебный штраф.

${ }^{108}$ От латинского глагола adstringere - связывать, понуждать.
В настоящее время данный процессуальный институт приобретает все большую популярность в мире, особенно в Европе. Конструкция особого судебного штрафа, преследующего цель оказать давление на волю должника или иного института, имеющего подобные функции, законодательно закреплена в странах Бенилюкса (Бельгия, Нидерланды, Люксембург), Греции (ст. 946 ГПК), Португалии (ст. 829-А ГК), Германии, Швеции, Израиле и т.д. Кроме того, нормы об особом судебном штрафе появились в Проекте процессуального кодекса Европейского Союза (ст. 13), разрабатываемого в рамках этой организации группой европейских ученых под руководством М. Сторме ${ }^{109}$. Несмотря на то, что исполнение судебных решений не входит в сферу регулирования Принципов трансграничного гражданского процесса УНИДРУА 2004 г. ${ }^{110}$, нормы ст. 29 Принципов («Эффективность судебных решений») предусматривают принятие государствами мер, обеспечивающих быстроту и действенность исполнения судебных актов, в том числе путем наложения штрафа.

Наконец, сам механизм применения особого судебного штрафа был недавно признан и lex mercatoria в рамках Принципов международных коммерческих договоров УНИДРУА 2010 г. ${ }^{111}$ (ст. 7.2.4. «Судебный штраф»). Данная статья устанавливает следующее: «(1) Если суд обязывает сторону произвести исполнение, он также может предписать ей уплатить штраф, если она не исполнит его решение. (2) Штраф должен быть уплачен потерпевшей стороне, если только императивные нормы права страны, где находится суд, не устанавливают иного. Уплата штрафа потерпевшей стороне не исключает заявления любых требований об убытках».

Первоначальная концепция особого судебного штрафа в процессуальном праве Франции основывалась на идее возмещения убытков,

\footnotetext{
${ }^{109}$ Storme M. (éd.) Rapprochement du droit judiciaire de l'Union européenne (Approximation of Judiciary Law in the European Union) // Bibliotheek van Gerechtelijk Recht. Dordrecht, 1994. Vol. 19. P. 6, 37.

${ }^{110}$ См.: Виноградова Е.А., Филатова М.А. Принципы трансграничного гражданского процесса (пер. с англ. яз.). М., 2011.

${ }^{111}$ См.: Комаров А.С. Принципы международных коммерческих договоров УНИДРУА 2010 (пер. с англ. яз.). М., 2013.
} 
причиненных неисполнением обязательства, наличие которого установлено судом. При этом суды отказывались присуждать штраф, превышающий размер причиненного ущерба. На практике подобный подход делал данный институт малоэффективным, поскольку должник знал, что с него никогда не взыщут больше того ущерба, который он и так должен возместить. 20 октября 1959 г. произошел перелом во французской судебной практике ${ }^{112}$. Суд кассационной инстанции решил, что особый судебный штраф является мерой принуждения должника к исполнению соответствующего судебного решения, не имеющей ничего общего с возмещением убытков. По мнению французского суда, поскольку особый судебный штраф выступает инструментом принуждения в частном праве (la peine privée), его размер может значительно превышать реальный ущерб кредитора ${ }^{113}$. Таким образом, институт особого судебного штрафа во Франции прошел путь от, по сути, иска о взыскании убытков до установленной процессуальным законодательством карательной меры частноправового характера ${ }^{114}$.

Законодательным источником, содержащим нормы, которые регулируют применение особого судебного штрафа, в настоящее время является Гражданский исполнительный кодекс Франции, вступивший в силу 1 июня 2012 г. (далее - ГИКФ) ${ }^{115}$. В соответствии со ст. L131-1 ГИКФ любой судья может по просьбе заинтересованной стороны, в том числе и по собственной инициативе, наложить особый судебный штраф в целях обеспечения исполнения своего решения независимо от характера присуждения. Это могут быть судебные решения об уплате должником денежного долга, о совершении им либо воздержании от совершения тех или иных действий,

\footnotetext{
112 l'Arrêt de la Cour de cassation française du 20 octobre 1959 // Recueil Dalloz. 1959. P. 537.

${ }^{113}$ Landrove J.C., Greuter J.J. L'astreinte: une mesure injustement boudee par le Code de procedure civile? // Revue de droit Suisse (RDS/ZSR), (3/2008), I. P. 275.

${ }^{114}$ Останина Е.А., Тараданов Р.А. Обзор литературы и нормативно-правых актов по истории возникновения и развития института (к статье «Проблемы и перспективы рецепции института астрэнта российским гражданским правом»). См.: $<$ http://m-logos.ru/img/Ostanina_Taradanov_astreinte.pdf $>$.

${ }^{115}$ См.: Code des procédures civiles d'exécution; article L131-1 article L131-4 < http://www.legifrance.gouv.fr>.
}

не связанных с уплатой денежного долга. Более того, при необходимости судья по исполнению судебных актов (le juge de l'exécution) вправе установить особый судебный штраф для обеспечения исполнения решения, вынесенного другим судьей. Согласно ст. L131-2 ГИКФ особый судебный штраф не зависит от наличия и размера убытков. Эта же статья предусматривает два вида такого штрафа - временный (l'astreinte provisoire) и постоянный (l'astreinte definitive). Особый судебный штраф по умолчанию считается временным, если только суд прямо не установил, что он является постоянным. Кроме того, в соответствии со ст. L131-2 ГИКФ постоянный особый судебный штраф может быть установлен (обязательно на определенный судьей срок) только после установления временного штрафа.

Как следует из ст. L131-4 ГИКФ, различие постоянного и временного особого судебного штрафа состоит в том, что размер временного штрафа может быть скорректирован судьей по исполнению судебных актов с учетом поведения ответчика, а также с учетом других обстоятельств, влияющих на исполнение должником судебного решения, в то время как размер постоянного штрафа не может быть изменен впоследствии. Согласно этой статье как временный, так и постоянный особый судебный штраф могут быть отменены полностью или в части, если будет установлено, что задержка в исполнении либо неисполнение судебного постановления происходит (полностью или в части) из-за внешних причин.

Посмотрим, как конструкция особого судебного штрафа применяется на практике. Мы знаем, что судья налагает такой штраф с целью обеспечения исполнения должником вынесенного судебного решения. При этом словесная формула судебного акта о наложении штрафа может выглядеть следующим образом: «Присуждаю господина Primus к исполнению обязательства господину Secundus с назначением особого судебного штрафа в размере 100 евро за каждый день просрочки такого исполнения. Штраф начисляется со дня вынесения настоящего постановления либо с момента его вручения должнику судебным исполнителем (l'huissier de justice)». Начисление штрафа начинается чаще всего после истечения определенного срока (например, по прошествии 30 дней) после вручения судебным исполнителем 
соответствующего судебного акта должнику. Причиной предоставления такого срока для исполнения судебного решения является желание суда дать должнику возможность добровольно исполнить обязательство перед кредитором. В очень редких случаях при крайней срочности исполнения штраф исчисляется со дня вынесения судебного постановления.

Если в описанном выше примере должник не подчинится судебному предписанию и не исполнит добровольно в указанный срок обязательство кредитору, то он должен будет заплатить 100 евро за каждый день просрочки исполнения. В действительности, чтобы получить денежное присуждение, Secundus должен обратиться к судье, вынесшему соответствующее решение, либо к другому судье (таким другим судьей, в принципе, может быть только судья по исполнению судебных актов) и продемонстрировать, что Primus не выполнил свои обязательства в срок, в связи с чем необходимо прибегнуть к особому судебному штрафу. На этом этапе временный особый судебный штраф «превращается» в постоянный. Судья не определяет размер штрафа математически путем подсчета суммы денежного присуждения. Учитывая специфику обстоятельств и не отменяя решения о назначении особого судебного штрафа, судья может смягчить наказание, если на это будут указывать факты, доказанные Primus и свидетельствующие об отсутствии его вины. Если из представленных суду доказательств будет явно видно недобросовестное поведение должника и его упорное нежелание исполнить соответствующее обязательство кредитору, суд назначит на строго определенный срок более суровое наказание в виде увеличенного в размере штрафа.

26 ноября 1973 г. правительства государств, входящих в экономический союз под названием Бенилюкс (Benelux), заключили конвенцию, имеющую целью введение в законодательство государств-членов (Бельгии, Нидерландов и Люксембурга) положений, унифицирующих правила об особом судебном штрафе (в качестве Приложения к конвенции выступает Закон, унифицирующий правила об особом судебном штрафе). Конвенция была ратифицирована государствами-участниками и вступила в силу для Люксембурга 30 ноября 1976 г., для Нидерландов - 8 августа 1978 г. и для Бельгии - 31 января 1980 г. Закон, унифицирующий правила об особом судебном штрафе, содержит 8 статей, юридическое содержание которых в целом соответствует современному французскому законодательству о данном процессуальном институте. В данной научной работе использованы результаты, полученные в ходе выполнения проекта «Кодификационные и унификационные процессы в международном частном праве», выполненного в рамках Программы «Научный фонд НИУ ВШЭ» в 2013 году, грант № 12-05-0020.

Настоящая статья подготовлена при поддержке Правовой информационно-справочной системы «Консультант Плюс».

\section{Библиография:}

1. Антонов И.В., Ружицкая Н.В. Механизм разрешения международных коммерческих споров // Закон. 2008. № 1 .

2. Белоусова О.В. Источники правового регулирования в рамках Европейского Союза: унификация международного частного права // Журнал зарубежного законодательства и сравнительного правоведения. 2011. № 6.

3. Беляева Н.Г. Особенности рассмотрения дел с участием иностранных лиц в арбитражном суде: Учебное пособие. М., 2012.

4. Виноградова Е.А., Филатова М.А. Принципы трансграничного гражданского процесса (ALI / UNIDROIT Principles of Transnational Civil Procedure). M., 2011.

5. Воронцова И.В. Об обязательности международных договоров по вопросам гражданского процесса // Современное право. 2011. № 3.

6. Елисеев Н.Г., Вершинина Е.В. Международное гражданское процессуальное право: Учебное пособие. М., 2011. 
7. Комаров А.С. Принципы международных коммерческих договоров УНИДРУА 2010 (пер. с англ. яз.). М., 2013.

8. Мамаев А.А. Международная судебная юрисдикция по трансграничным гражданским делам. М., 2008.

9. Осавелюк Е.А. Международный гражданский процесс России. М., 2006.

10. Осминин Б.И. Разрешение коллизий между внутригосударственным правом и международными договорами // Журнал зарубежного законодательства и сравнительного правоведения. 2013. № 1.

11. Петрова М.М. Особенности правового регулирования доказательств в международном гражданском процессе // Адвокат. 2011. №

12. Степин А.Б. Понятие и сущность международных стандартов защиты частного права // Международное публичное и частное право. 2012. № 1.

13. Хоцанов Д.А. Установление содержания иностранных правовых норм в международном частном праве. М., 2012.

14. Швакин С.В. Проблемы международного взаимодействия национальных правовых систем // Евразийский юридический журнал. 2012. № 6.

15. Юрова Н.М. Международное гражданское процессуальное право: Теоретические основы имплементации норм в правовой системе РФ. М., 2008.

\section{References (transliteration):}

1. Antonov I.V., Ruzhitskaya N.V. Mekhanizm razresheniya mezhdunarodnykh kommercheskikh sporov // Zakon. 2008. № 1.

2. Belousova O.V. Istochniki pravovogo regulirovaniya v ramkakh Evropeiskogo Soyuza: unifikatsiya mezhdunarodnogo chastnogo prava // Zhurnal zarubezhnogo zakonodatel'stva i sravnitel’nogo pravovedeniya. 2011. № 6.

3. Belyaeva N.G. Osobennosti rassmotreniya del s uchastiem inostrannykh lits v arbitrazhnom sude: Uchebnoe posobie. M., 2012.

4. Vinogradova E.A., Filatova M.A. Printsipy transgranichnogo grazhdanskogo protsessa (ALI / UNIDROIT Principles of Transnational Civil Procedure). M., 2011.

5. Vorontsova I.V. Ob obyazatel'nosti mezhdunarodnykh dogovorov po voprosam grazhdanskogo protsessa // Sovremennoe pravo. 2011. № 3.

6. Eliseev N.G., Vershinina E.V. Mezhdunarodnoe grazhdanskoe protsessual'noe pravo: Uchebnoe posobie. M., 2011.

7. Komarov A.S. Printsipy mezhdunarodnykh kommercheskikh dogovorov UNIDRUA 2010 (per. s angl. yaz.). M., 2013.

8. Mamaev A.A. Mezhdunarodnaya sudebnaya yurisdiktsiya po transgranichnym grazhdanskim delam. M., 2008.

9. Osavelyuk E.A. Mezhdunarodnyi grazhdanskii protsess Rossii. M., 2006.

10. Osminin B.I. Razreshenie kollizii mezhdu vnutrigosudarstvennym pravom i mezhdunarodnymi dogovorami // Zhurnal zarubezhnogo zakonodatel'stva i sravnitel'nogo pravovedeniya. 2013. № 1.

11. Petrova M.M. Osobennosti pravovogo regulirovaniya dokazatel'stv v mezhdunarodnom grazhdanskom protsesse // Advokat. 2011. №

12. Stepin A.B. Ponyatie i sushchnost' mezhdunarodnykh standartov zashchity chastnogo prava// Mezhdunarodnoe publichnoe i chastnoe pravo. 2012. № 1.

13. Khotsanov D.A. Ustanovlenie soderzhaniya inostrannykh pravovykh norm v mezhdunarodnom chastnom prave. M., 2012.

14. Shvakin S.V. Problemy mezhdunarodnogo vzaimodeistviya natsional'nykh pravovykh sistem // Evraziiskii yuridicheskii zhurnal. 2012. № 6.

15. Yurova N.M. Mezhdunarodnoe grazhdanskoe protsessual'noe pravo: Teoreticheskie osnovy implementatsii norm v pravovoi sisteme RF. M., 2008. 